\title{
Отношение стиха к графике и читке: вопросы онтологии стихотворной речи
}

\section{Юрий Патюпо}

Центр исследований белорусской культуры, языка и литературы Национальной академии наук Беларуси paciupa@gmail.com

Аннотация: Важнейшей задачей стиховедения является стратификация уровней стиха в связи со стратификацией языка и речи. Решение этой задачи позволяет вскрыть отношения стиха к устным и письменным актам речи и дает ключ к плодотворному изучению как произведений устного народного творчества, так и авторских текстов. В работе последовательно рассматриваются отношения, возникающие между уровнями и разными планами языка, речи, и собственно стиха. Предлагаемое решение развивает и углубляет иерархическую модель стиха, разработанную еще в античности. На ряде примеров автор доказывает несводимость структуры стиха ни к его графике, ни к читке и критически пересматривает распространенное понимание стиха как речи с «двойной сегментацией». Внимательное изучение стихотворной графики и вербальной структуры выявляет в стихотворных текстах сложные отношения симметрии и диссимметрии, в которых видятся, соответственно, начала стиха и прозы. C учетом полученных выводов автор деконструирует антидекламационные установки в стиховедении и предлагает различать три разновидности читки: скандовку, рецитацию и декламацию, последняя из которых делится на напевную и риторическую. Особое внимание уделяется рецитации как читке, позволяющей диагностировать вариации и модификации ритма. В конечном счете автор приходит к выводу, что стихотворная речь осуществляется за счет парцелляции сегментов материального плана, а исходной единицей стихотворной 
речи является изоколон, механизмом же, активизирующим все уровни речи и способным порождать метрику, является изосиллабизм.

Ключевые слова: уровень, язык, речь, стих, проза, элемент, конструкт, слог, слово, синтагма, фрраза, стопа, колон, период, симметрия, асимметрия, диссимметрия, графика, сегментация, парцелляция, скандовка, рецитация, декламация

\section{Введение}

Всякая речь, прозаическая или же поэтическая, реализуется в речевом акте, устном или письменном. В связи с этим неизбежно возникает проблема соотношения, с одной стороны, стиха и его звучания, с другой стороны - стиха и его графики. Среди других стиховедческих проблем они на первый взгляд могут даже показаться второстепенными, но на самом деле без них вообще невозможно решить фрундаментальную стиховедческую проблему - соотношение стиха и прозы. Вернее было бы сказать, что все теоретические вопросы стиховедения продуктивнее решать в комплексе, и поскольку стих является одним из типов речи и своеобразным художественным языком, то, прежде чем обратиться к указанным проблемам, необходимо выяснить, каким образом әлементы стиха соотносятся с уровнями естественного языка.

Уровневый подход стал широко распространяться во второй половине XX века как «проблема номер один современной лингвистики» (Слюсарева 1969: 269), но в области стиховедения не получил должного применения, более того, многие противоречия и тупиковые решения происходят именно из-за отсутствия уровневой стратификации элементов стиха. И, тем не менее, уровневый подход к стиху был с успехом применен еще в античности. Если отбросить школьное представление об античной теории стиха как о наборе стоп - схем чередования сильных и слабых позиций, то главным окажется то, что античная теория разработала учение о соподчинение единиц стиха: мора, стопа, колон, период, строфа (Денисов 1888). Это очень напоминает порядок сегментации текста, принятый в современной лингвистике: звук, слог, слово ${ }^{1}$, синтагма ${ }^{2}$, фраза (Бондарко $\&$ Вербицкая $\&$ Гордина 1991). У некоторых единиц обоих рядов существуют аналоги: колон и синтагма, период и фрраза, но на более низ- 
ких уровнях аналогия не так очевидна: мора не соответствует звуку, скорее слогу, а стопа очень слабо соотносима со словом. Впрочем, не стоит забегать наперед, для начала необходимо выяснить, как эта иерархия коррелирует с уровнями языка, и коррелирует ли вообще.

\section{Стих и уровни языка}

Со времени появления известной статьи ${ }^{3}$ «Уровни лингвистического анализа» (Бенвенист 1974: 129-140) написано очень много работ об уровнях языка. У нас нет возможности включаться в полемику по этому поводу, хотя бы потому, что проблема уровней здесь присутствует как фон для решения собственно стиховедческих проблем. Вместо подробного анализа предлагаем краткое изложение нашего видения картины уровней языка. Кроме названной статьи Э. Бенвениста здесь были применены некоторые идеи А. М. Мухина (Мухин 1976). Для вынесения проблемы уровней за сугубо лингвистические рамки большое значение имели работы Ю. М. Лотмана, в частности (Лотман 1970). Правда, вне лингвистики уровни имеют несколько амбивалентный характер, мы же в данном исследовании стремимся к точному определению уровней стиха. Главное же, не засорять теоретическую модель избыточными сущностями и не обнадеживаться очевидностью схемы, так как констатация системности и иерархичности без понимания сущности обесценивает саму идею уровней. Уровни языка выделяются по элементам: фонема, морфема, лексема, словосочетание, предложение. Элементы низшего уровня входят в высший как интегранты, а на собственном уровне образуют конструкты, которые становятся элементами следующего уровня, и т. д. Это соподчинение можно показать на схеме:

$$
\text { интегрант } \leftarrow \text { элелент } \rightarrow \text { конструкт }
$$

Крайние уровни языка - верх и низ - отличаются неполнотой: фонема, как минимальный элемент, не включает интегрантов, а предложение, являясь конструктом синтаксического уровня, не входит в более крупные языковые конструкты, поэтому не существует и грамматики текста. «Предложение содержит знаки, но само не является знаком» (Бенвенист 1974: 139). 
Каждый уровень имеет свой семантический план, недоступный непосредственному наблюдению, часто эти планы ошибочно рассматриваются как один уровень. Посредством семантики уровни иерархически организуются, образуя страты. Иерархию можно представить следующим образом. Знак, как составляющая парадигмы, имеет значимость, а включаясь в синтагму ${ }^{\mathrm{s}}-$ приобретает еще и значение, тем временем значимость отступает на другой план. Эта процедура повторяется на каждом уровне, но с приращением новых составляющих. Если фонеме присуща значимость, то морфемы имеют и значимость, и значение, в словах появляется рефреренция как дополнительный ингредиент, а в предложении - предикация. Включенность в жизненный контекст придает предложению смысл, в зависимости от цели речевого акта: информативный, перформативный, формальный и т. д. Можно сказать, что в данном движении по спирали всякий раз содержание низшего уровня становится формой для высшего (ср. Барт 1989: 78-80).

У ровни так плотно организованы, что приписывание системе излишней сущности, как и непродуманная классификация составляющих, не обогатит теорию, а будет только вносить в нее эклектику и разрушать системность. Поэтому при изучении иерархической системы языка принципиально важно различать такие вспомогательные категории, как уровень, план, слой, ряд, сдрера, аспект и т. п. Даже если категоризация не совсем удачна - различение сфрер предпочтительнее, чем дурная бесконечность уровней. Как мы писали, нет семантического уровня языка, но есть семантический план, релевантный для всех уровней. A, например, такие области языка, как словообразование или стилистика, вообще не относятся к онтологическим уровням, являя собой скорее гносеологические сферы, где пересекаются разные уровни. С другой стороны, если принять во внимание обстоятельство, что на каждом уровне есть и парадигматика, и синтагматика, и соответствующий инвентарь единиц, то для каждого уровня должна существовать отдельная морфология, синтаксис и семантика. И, заметим, распространенные среди структуралистов попытки освободиться от семантики не только напрасны, но и вредны. А во избежание вульгаризации семантики не следует элементам низшего уровня приписывать семантических свойств высшего уровня. 
Если же абстрагироваться от системной организащии языка и взглянуть на нее в телеологической перспективе как на средство коммуникации, то все сводится к материальным носителям и выражению смысла. С одной стороны, язык опирается на фризическую реальность - звучание, с другой стороны, физическая реальность в процессе коммуникации потребляется, чтобы как можно более полно превратиться в субстанцию идеальную мышление. А если сопоставить уровни, то самый «языковой», отчетливо знаковый статус будут иметь морфемы и слова - то, что уже не звук, но еще и не смысл. Они, хотя и соподчинены, представляют единую сферу, пронизанную взаимными конверсиями. Известно, что при возрастании синтетизма возрастает свобода лексических единиц в предложении, зато ассоциация морфем в пределах слова предельно жесткая. И наоборот, жесткая организация предложения в аналитических языках как бы компенсируется свободным существованием морфем. Таким образом, статус и аффиксов, и служебных слов примерно одинаков, и те, и другие значимы, но беспредметны. Зато корневые морфемы в отличие от афрфиксальных - предметны, предметность возникает уже на этом уровне, а в слове, как

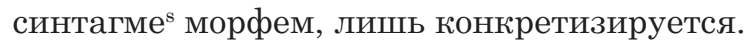

Элементы уровней неоднородны, при внимательном рассмотрении на каждом уровне среди общего ряда элементов выделяются элементы особые, которые можно назвать ядерными: среди фонем - синдемы ${ }^{4}$ и просодемы, среди морфем - корни, среди словосочетаний - предикативные конструкции. Так или иначе, их принято различать в общем ряду как нечто качественно иное. В конструкт обычно входит один ядерный элемент, и лишь изредка два или больше. Ядерные элементы выступают координаторами в конструктах, воплощая присутствие высшего уровня на низшем ${ }^{5}$. Одной ядерной единицы достаточно, чтобы перейти на более высокий уровень, а иногда и охватить все уровни, от низшего до высшего, от фонемы до предложения. Но при этом среди слов труднее выделить ядерные элементы, чем среди морфем, а среди предложений их и вовсе нет, зато слова и предложения доступны наивному сознанию - это своего рода итоговые конструкты. А фонемы, морфемы и словосочетания, где заметны ядерные элементы, доступны глазу только при специальном анализе. На основании этих различий мы можем предположить, что несколько уровней могут объединяться 
в ярус по итоговым элементам: слов и предложений. Впрочем, к стиху все это имеет косвенное отношение, в нем актуальна иная иерархия, к которой и обратимся.

Обратившись, наконец, к иерархии сегментационных единиц текста: слог, слово ${ }^{f}$, синтагма, фрраза и т. п., мы увидим, что на шкале уровней языка для них не находится места. Более того, эти единицы изучаются на одном, низшем, уровне, как объекты фонетики, сегментной фонологии, просодии и т. д. Можно ли говорить об уровнях, когда переход от единицы более мелкой к крупной не сопровождается возрастанием значимости? С другой стороны, можно ли сказать, что переход от слога к слову или от синтагмы к фразе - это только количественное, не связанное со смыслом высказывания членение? В конце концов, сегментация высказывания, начиная уже со слова, подчиняется семантическим задачам, хотя переход от меньшего к большему здесь и не сопровождается семантической стратификацией, диалектикой содержания и формы, движение происходит не по спирали, а линейно. Форма - всегда из того же фонетического материала, лишь более или менее продолжительна, содержание - всегда предметно, лишь более или менее полно. Наконец, мы имеем дело не с элементами, а с сегментами. Главное же отличие сегментной иерархии от уровневой в том, что все ее ступени, от звука до фразы, - это единицы речи. Если язык по Э. Бенвенисту заканчивается на предложении, то речь не оканчивается фразой, а охватывает тексты. С текстами же обычно имели дело логика, риторика или поэтика, но не грамматика.

Идентифицировать сегментационные единицы как явления речи очень важно, но это не раскрывает их отношения к вертикали языка. Все единицы языка - и фонемы, и морфемы, и лексемы - тоже имеют свои реализации в речи, но те не совпадают с единицами сегментации. И нельзя сегменты речи противопоставить элементам языка как чисто фрормальное явление, так как у единиц языка, как уже отмечалось, тоже есть своя форма. И, если слог - это форма, то фрорма чего? Морфема может сводиться к одной согласной фонеме и тем самым быть меньше слога, а может включать и несколько слогов. Здесь как раз кстати вспомнить о многозначности слова фборла, которое довольно часто запутывает теоретиков. Есть фо о м а соде р жания и форма материала.Изначения их различаются не степенью абстрактности, а полной несовместимостью. Если 
мы возьмем яблоко и будем рассматривать его округлость, цвет, вкус, то будем иметь в виду материал. А если вспомним «яблоко раздора», «яблоко с древа познания добра и зла», то их физические, химические и геометрические свойства нас будут мало интересовать. Тогда все яблоко будет формой. Даже если мы и очертания, и цвет яблока примем во внимание, то все равно в другом смысле - как символы. Значит, в одном случае речь идет о форме материала, а в другом - о форме содержания. И речь сегментируется именно как материал, не сам по себе, а "раскроенный» под «тело» знаков, о чем тоже никогда не следует забывать.

Таким образом, обращаясь к сегментации текста, мы изучаем речь. И именно в формальном или, более точно, м а т е р и а ль н о м плане. Иерархия сегментов речи коррелирует с иерархией уровней языка только релятивно. И в то же время, сегменты речи, являясь материальными объектами, полностью зависимы от идеальной цели высказывания ${ }^{6}$. Если звуки и слоги еще чисто формальные единицы, то далее, начиная со слова, все единицы сегментации осмыслены, поэтому: «Синтагма - понятие не столько фонетическое, сколько синтаксическое и семантическое» (Виноградов 1975: 113), ведь «синтагма, по В. В. Виноградову, әлемент речи, а не языка» 7 (Реформатский 1975: 23), а «вопрос о том, можно ли к ним применять «эмическую терминологию» [...] мы пока оставим открытым» (там же: 50). Однако семантика единиц речи отличается от семантики единиц языка, ее структура не стратифицирована по вертикали, а наоборот, линейна и фррагментарна, как отрезок растворенного в тексте одного цельного смысла. "Смысл синтагмы зависит от смысла целого» (Виноградов 1975: 114). «Сукцессивность обязательна для линейной речи», «а симультанность в речи затруднена именно этой сукцессивностью; языку же, как системе [...] - сукцессивность принципиально противопоказана» (Реформатский 1975: 54).

Теперь же, если обратиться к ритму, который и есть объект нашего интереса, то можно заметить: членение обычного прозаического текста, в движении от слова к синтагме, от синтагмы к фрразе, не представляет собой самостоятельного ряда, и его ритм, если таковой существует ${ }^{8},-$ результат скопления знаков, объем которых случаен и непредсказуем, сами они в речи на высших уровнях фризически неразличимы. Но зато материальные сегменты на этих уровнях осмыслены, и иного фризиче- 
ского членения не наблюдается, поэтому можно сказать: ритм прозы слепо следует за смыслом. Но из этого вовсе не следует, что ритм носитель смысла. Превращение ритма в иероглиф, попытка читать как ребус - распространенная логическая ошибка, которая в итоге приводит к вульгарным трактовкам семантики (объект частой критики Л. И. Тимофеева). Текст же стиха помимо речевого, принято считать, имеет дополнительное членение. Какова природа этого членения, какие уровни и планы оно охватывает, - это и предстоит выяснить. Иными словами, мы должны выяснить, насколько верно определение стиха как речи с «двойной сегментацией». М. И. Шапир по этому поводу писал: «Наибольшие сомнения вызывает характеристика стиховой сегментации как “двойной”. Даже проза, помимо синтаксических, имеет немало других членений, причем границы значимых единиц не всегда совпадают с границами единиц незначимых» (Шапир 1996: 42). Но, как мы выяснили, языковые единицы непосредственно не участвуют в образовании ритма. Ритм - принадлежность материального плана.

В целом, с критикой «двойной сегментации» нельзя не согласиться, но и альтернатива, предложенная М. И. Шапиром, вряд ли приемлема. Развивая некоторые идеи Р. Якобсона, он приходит к выводу: «В отличие от прозы стих содержит проходящие через весь текст, т. е. сквозные, принудительные парадигматические членения» (Шапир 1996: 46). Парадигму чего содержит стих? Интерпретация строк как парадигмы обнаруживает фундаментальное непонимание ее сущности. Видимо, здесь оказало свое влияние графическое оформление

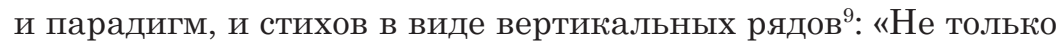
важна сукцессивная последовательность, но и симультанное целое, будь то сонет Петрарки» (Реформатский 1975: 54). Шапир предлагает рассматривать текст в виде пространственно-временного континуума синтагматических и парадигматических сегментов. Метафорически и даже концептуально такой континуум можно представить, но в том-то и дело, что природа языка и всех его парадигм не пространственная и не временная, а тр ансцендентальн а я ${ }^{10}$; не текстовая, а надтекстовая. И наконец, парадигма потому и парадигма, что представляет некоторое замкнутое целое, а не развернутое в бесконечность, как строки стиха. 
Но из критики "двойной сегментации» вовсе не следует, что стих не имеет специфических членений (сколько бы их ни насчитывалось), этого не отрицал и М. И. Шапир. Рассуждать о членении, не имея представления о составляющих - бессмысленное занятие, поэтому первое, что мы должны сделать, это определить единицы стиха, а в идеале - найти его элементарную единицу, из которой выводится вся иерархия стихотворной речи. Единицей такого рода принято считать строку, по большому счету, понятие «двойной сегментации» к членению на строки и сводится. Строка в центре внимания оказывалась дважды: вопервых, в связи с демаркацией стиха и прозы - как сегмент не свойственный прозе, во-вторых, в связи с критикой стопы - как әлементарная единица стиха, альтернатива стопе. Первую идею высказал в 1923 г. М. М. Кенигсберг: «Стихотворной (точнее “стихической”) речью мы должны признать речь, разбитую на ряд заключенных в себе единств, не связанных обязательной связью с логическим или синтаксическим членением, - единств, объединенных (графически) однородной системой разделения и (акустически) однородной интонацией концов» (Кенигсберг 1994: 156). Этот случай относится к проблеме «двойной сегментации», но не проблеме первоэлемента стиха, которая возникла еще раньше.

Такую идею выдвинул В. Чудовской: «Единица - стих (строчка). Это неоспоримый, реальный, основной элемент в стихотворной речи» (Чудовской 1915: 57). До этого в качестве первоэлемента подразумевалась стопа, отсюда и «стопосложение». Теперь же было объявлено: «Стопы не существует» (там же: 59). Относительно других сегментов сделан вывод: «Слог - это лишь мера; единственным же вещественным элементом внутри стиха есть слово» (Там же: 60). Позже идею Чудовского развил Л. И. Тимофеев: «Определяют ритм стиха как слоговой, тогда как на самом деле единица стиха крупнее: ритм его создается чередованием строк, а не “стоп”» (Тимофеев 1928: 29). Дополнением к Чудовскому было выдвижение на первый план константы и других ударений: «Стихотворный ритм создается из двух моментов: первый момент - конечное ударение - определяет данное речевое движение просто как стих, делит на единицы; второй - внутренние ударения - определяет это движение уже как конкретную систему стиха, соизмеряет единицы» (Тимофеев 1928: 28-29). Взаимодействие константы со второстепенными 
ударениями было раскрыто позже, в «контрольных рядах» А. П. Квятковского (Квятковский 2008: 9-33) и концепции регрессивной акцентной диссимиляции К. Тарановского (Тарановский 2000) как универсальном механизме стиха (см. Пацюпа 2017: 661).

Это не что иное, как мучительное движение к истокам. В. Чудовский об этом догадывался, когда в конце своей статьи добавил, забыв и отрицание стопы: «Древние [...] ритмовой единицей признавали не стопу, а пару стоп. Еще важнее их учение о распадении стиха на два kola. Я лично отчасти склонен ощущать стих как диаду и даже отрицать органическую цельность понятия “стих": возможно, что настоящей ритмовой единицей является не стих, а то, что мы называли бы полустишие, в парных соединениях. Здесь смысл цезуры» (Чудовской 1915: 70). Как только современное стиховедение пытается открыть что-либо существенное в механизме стиха, оно постоянно наталкивается на категории, изобретенные еще в античности. Но было бы несправедливо говорить, что ничего принципиально нового не открыло новое стиховедение. Античная ортометрия выработала терминологический аппарат, но не объясняла, каким образом стих фрункционирует как система, как относится к языку в целом и к каждому уровню в частности. Это мы должны выяснить, опираясь на сказанное.

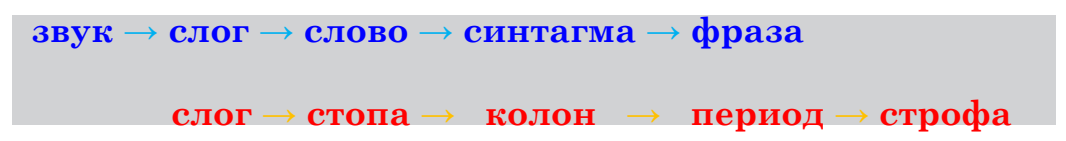

Соотношение рядов речи и стиха.

Итак, всякая речь - стих или проза - вне зависимости от типа, имеет сегментацию: сигнификативную и материальную. Раздвоенность - результат нетождественности как самой иерархии, так и элементов каждого уровня. Но если бы нетождественность была абсолютная, то не было бы и основания для сравнения. На самом деле такое основание есть, не только потому, что объект анализа совпадает, но и потому, что каждый уровень, как сигнификативного, так и материального планов, имеют определенный метауровень: 1) фонема - звук; 2) морфема - слог; 3) слово - фонетическое слово; 4) словосочетание - синтагма; 5) предложение - фрраза. В полной мере совпадают лишь фонема 
и звук - они одинаково присущи как сигнификативному, так и материальному планам ${ }^{11}$. Можно ли выделить третий план или ряд - стиховой? Античная традиция предоставляет такую возможность: слог соответствует слогу же (мора - в моросчитающих языках), слово, в некоей мере, - стопе, синтагма - колону, период - фрразе. Лишним оказывается звук (именно звук, ибо фонема принадлежит иному ряду), и очень сомнительно выглядит соответствие слова и стопы. Недаром В. Чудовской и Л. И. Тимофеев так настойчиво выдвигали на место стопы слово, но, как и подмена фонемой звука, - это некорректное привнесение в материальный план и стиховой ряд единиц сигнификативного плана.

Если по Ю. Н. Тынянову «конструктивным принципом» стиха является ритм (Тынянов 1965: 36-43), то понятно почему минимальной единицей стиха будет не звук, тем более не фонема, а элемент высшего уровня. «Слоги в совокупности своих акцентных вершин представляют собой кратчайшие звенья ритмической организации речи» (Трахтеров 1956: 16). Почему слоги или моры (а не «звуковые повторы» ${ }^{12}$ ) могут быть минимальным элементом стиха? Потому что они соизмеримы во времени. Но, как и все минимальные единицы, это пограничные явления: как звуки принадлежат и природе и речи, так слоги принадлежат и речи и стиху. Какая же единица является первым конструктивным элементом стиха? Исторически и логически им может быть только колон. Колон конструируется из слогов - сегментов, релевантных как для стиха, так и речи вообще, но сам является уже принадлежностью именно стиха ${ }^{13}$, строка же - производная от колона. В фольклорном стихе строки нет, есть лишь колоны и периоды ${ }^{14}$. Как мы убедимся ниже, понятие строки по отношению к фольклору противоречиво: она может включать и один колон, и два, и больше, может быть частью периода, а может и охватывать период целиком, при этом разбивка на строки производится субъективно, по воле публикатора. Что касается стопы, то мы не спешим с ее отрицанием. Колон восходит к синтагме, а константа обладает всеми чертами синтагматического ударения. В основе же стопы лежит словесное ударение, каким образом, на какой стадии развития стиха из ударных и безударных слогов образуются стопы - тоже предстоит выяснить, а также - статус существования стоп. 
Все выше сказанное можно обобщить в метафоре: если материальный план вообразить как рассеченный рельеф, то знаки языка будут рисунками, нанесенными на поверхность рельефа. И, если перед нами незнакомый язык, то, хотя бы мы и обладали абсолютным прибором, позволяющим различить все материальные сегменты, мы не сможем расшифровать текст, потому что не владеем его кодом. Зато рельеф оказывается в какой-то мере вне рисунков, вне кода. В романе Осипа Сенковского «Ученое путешествие на Медвежий Остров» сталактиты были прочитаны как текст, на самом же деле текст может быть воспринят как «сталактиты», но никак не наоборот. А. Г. Волков, используя метафору Н. Винера, противопоставил сигнал шуму, как организм хаосу (Волков 1966: 12). Это очень сомнительная аналогия, в материальном плане речи нет ничего, что отличало бы ее от хаоса. Лишь наличие кода в нашей голове, то есть не только означаемого, но и означающего, позволяет отличить речь от «сталактитов». Но и в сталактитах можно отличить порядок от хаоса, симметрию от асимметрии и диссимметрии. Таким же образом мы отличаем (но не более того) стихотворную речь от прозы, даже не зная языка. Может, потому, что в оппозиции симметрии и хаоса есть нечто доязыковое, «разнообразные способы внесения в текст на различных его уровнях законов симметрии, лежащих в основе пространственной семиотики и не присущих структуре естественных языков» (Лотман 1995: 104).

Итак, сигнификативный план полностью исключается как не имеющий к стиху отношения, материал для стиха предоставляет материальный план, но при этом звуки не могут быть әлементами ритма, так как не образуют конструктов ритма, слоги уже выступают элементами и мерой, но стопы пока неопределенны и необязательны, а элементарными единицами выступают колоны, которые объединяются в периоды. Каким же путем образуется стих? Ответ напрашивается лишь один: в результате реорганизации материального плана по законам симметрии и / или ритма ${ }^{15}$, «симметрия ритма [...] зачастую деспотически подчиняет себе слово» (Елатов 1966: 77). Этот вывод мы и возьмем в качестве рабочей гипотезы. 


\section{Отношение стиха к графике}

Следует заметить, ритмизация материального плана в народной поэзии не нарушает границ речевых структур (ведь в ней нет анжамбемана), а только задает для них рамки. Разбалансировка коммуникативного и стихового рядов возникает позже, на определенных этапах развития литературы, да и то без всякой регулярности, поэтому вряд ли можно согласиться с теми, кто считает анжамбеман едва ли не главным показателем стиха (Невзглядова 1994: 82). Но тождество коммуникативного и стихового рядов не должно вводить в заблуждение, будто бы синтагма и колон нечто одно. Также и в литературе необходимо различать графическую сегментацию (которой в фольклоре нет) от собственно стиховой (необходимой и в фольклоре, и в литературе), хотя графика в значительной мере и призвана подчеркивать ритм. Вариативность графического оформления ритмических структур наглядно раскрывается на письме. Один и тот же фольклорный размер допускает несколько одинаково правильных графических решений, ни одно из которых не может считаться безоговорочно правильным. Совершенно иначе в литературе, где последнее слово остается за автором. Но и в литературе вариативность графики нельзя исключить, что говорит о ее относительной независимости от внутреннего вербального ритма.

В качестве примера рассмотрим графические вариации одной строфы в различных авторских исполнениях. Исходная версия - строфра, состоящая из двух периодов четырёхстопного анапеста с цезурой и трёхстопного анапеста без цезуры (Кп. 2: 91):

Ноч за ночкай ідзе, I| сцішна, тайна брыдзе,

Рассявае трывогу-знямогу;

Цені густа кладзе | | на пяску, на вадзе,

Ацямрае гасцінец-дарогу.

(Янка Купала)

Этот размер до такой степени выразителен, что никакие дальнейшие графические изменения не введут нас в заблуждение и не закамуфлируют его глубинного тождества при варьировании. Такой же анапест превращается в шестистишие, если длинная строка по цезуре делится на две кратких (АЖПП: № 10): 
На палі, на лугі,

На пагуркі, лясы

Майскі вечар паволі спусціўся.

Звільгатнела зямля,

Легла густа раса,

Ясны дзень цёмнай ночкай змяніўся.

(Ванда Ллвіцкая)

Отрывок из Левицкой благодаря единству тематики вообще звучит как продолжение купаловского стихотворения.

Если же произвести неполное членение длинных строк, то получится пятистишие (АЖП: № 12):

На чужым берагу || мы з табою адны...

Навакол злая ўюга бушуіць...

I штодня сніцца мне

Як ў радной старане

Сонца ласкай п’яніць і калдуіць.

(Вольга Сахарава)

Но даже в трёхстопной строке можно провести графическое членение по диерезе и рифме, исключив одностопный пуант, а периоды выделить как отдельные строфы - квази-двустопные, если не считать пуанта (АЖП: № 12):

Было цёмна кругом...

На дварэ за акном,

Вецер выў і спяваў весяліўся.

Снег ляцеў, вар'яцеў...

Ведзьма, лешы ці чорт

Там вяселле спраўляў -

ажаніўся.

(Галена Іванова)

Все представленные оформления размера были произведены не нами, а их авторами по тем или иным эстетическим соображениям.

Конечно, можно сказать, что перед нами четыре разных размера. И, тем не менее, нельзя игнорировать некоторого метрического тождества данных строф. Но если так, то, очевидно, отличаются графические структуры. Что же здесь тождественно? Собственно стиховая структура? По-видимому, именно так. Вербальная структура - коммуникативный ряд и стиховой, графи- 
ческая же-представляет третий, отличный от них ряд. Причем все три относятся к материальному плану. Конечно, резонно возразить, что отличия в графике предполагают разницу в читке, но какое это имеет значение, если известное направление отделило стих от декламации (Гаспаров 1974: 294-299). Ведь сумма декламации и графики - это еще не собственно структура стиха. Но что примечательно, и стиховой ряд, и графический одинаково симметричны, чем подчеркивается их связь. Теория «двойной сегментации», фрактически, не видит этой разницы и ставит знак равенства между ритмической структурой текста и его графикой. В устном народном творчестве графического ряда нет, вернее, он привносится извне, во время публикации. Но это не значит, что фольклор ограничивается вербальным рядом. Если нет графического ряда, то есть музыкальный, декламационный - к ним тоже иногда пытаются свести вербальный ряд. Те, кто призывает отличать стих и декламацию, делают еще большую ошибку, когда смешивают стих и его графику.

По-видимому, между графикой и декламацией существуют отношения конверсии. Ведь «авторская установка на то, как воспринимать [...] [стихи], зафиксирована в их графике, диктующей и определенную форму их декламационного произнесения» (Руднев 1989: 37), хотя одно и несводимо к другому. При взаимной конверсии графики и декламации еще рельефнее проявляется первичность собственно вербальной структуры стиха и законов стихотворной организации материального плана на фроне коммуникативной организации того же материального плана. Спрашивается, а сколько же всего параллельных рядов в тексте? Лишь материальный план включает три ряда: 1) коммуникативный, 2) стиховой, 3) декламационно-музыкальный либо графический. Вне материального плана располагается еще сигнификативный ряд - нейтральный по отношению к стиху. Но дать исчерпывающий ответ о количестве рядов мы не беремся, да и не ставим такой цели. Существенно то, что в стихе постоянно борются два принципа организации: с одной стороны - ориентированный на с е м н т ику, с другой стороны - ориентированный на с им метр ию. В разных речевых актах, на разных уровнях поддерживается то один, то другой.

В этой оппозиции симметрии и семантики, симметрии и диссимметрии и заключается «секрет» «двойной сегментации», которая будто бы маркирует стих. С одной стороны, материальная 
оболочка текста служит вместилищем знаков, объем которых случаен и индиффрерентен к симметрии, с другой стороны, эта же оболочка подчиняется законам симметрии, нейтральным по отношению к смыслу. Если абстрагироваться от сигнификативного ряда, от многослойности материальной сегментации, то сама по себе идея «двойной сегментации» имеет смысл. Но не в ней отличие стиха от прозы - это какое-то недоразумение, логическая ошибка. Если бы поэзия отличалась от прозы только количеством членений, то эти членения должны иметь одну природу, а если они разнородны, то отличие не в их количестве, а в качестве того «членения», которое отсутствует в прозе. Но как раз от ответа относительно качества того «дополнительного» «членения» и уклоняется по сути теория «двойной сегментации», все свелось к графике или, еще более примитивно, к «строчкам». Наша рабочая гипотеза заключается в том, что искомое качество следует искать в симметрии. Конечно, далеко не все, что относится к стиху, симметрично, но в целом стремление к симметрии речи связано прежде всего со стихом.

Эта оппозиция наблюдается не только в вербальном ряду, т. е. в речи, но и в сопутствующих рядах - речевых актах. Как известно, есть два стиля декламации: напевный, характерный для исполнения поэтов, и риторический, распространенный среди актеров. Первый подчеркивает метрическую канву стиха, упор - на музыкальный аспект, а другой - игнорирует метр, здесь упор - на семантический аспект стиха. Музыкальное исполнение также воплощает стремление текста к симметрии, именно поэтому музыка в народной поэзии служит катализатором метричности, хотя и не заменяет ее. То же можно проследить и в графике - все четыре цитированные выше версии строфы демонстрируют различную игру симметрии / асимметрии и ни одна из них не диссимметрична. Таким образом, явления симметрии в музыке, декламации и графике необходимо отличать от симметрии в структуре самого текста.

Полученные результаты многое объясняют в поэтике верлибра и т. н. стиха Маяковского. Мы не можем подробно останавливаться на обеих темах, но не можем и обойти. В одной из дискуссий о верлибре М. Л. Гаспаров взял отрывок из статьи своей оппонентки, разделил на строки тремя способами: на длинные, короткие и контрастные, заявив, будто все три варианта можно считать верлибром в разных стилях. 
Тем самым он проиллюстрировал идею: «Свободный стих есть лишь записанная столбиком проза» (Гаспаров 1980: 209). Это крайнее, почти циничное, определение и есть единственно трезвое видение природы верлибра. В нем как в капле воды видны все преимущества и недостатки «двойной сегментации». Но, с другой стороны, если разделение на строки достаточное основание, чтобы текст считался стихотворным, то мы получим только малосодержательную теорию, из которой ни логически, ни исторически нельзя вывести классические формы стиха. Если же разделение на строки всего лишь одна из особенностей стиха, то возникает вопрос: какая именно? Из предыдущего анализа очевидно, что в верлибре присутствует графическая составляющая, чаще всего - диссимметричная. Фактически, верлибр осуществляет скачок от прозы к графике, минуя главное, вербальную организацию. Мы не будем уточнять, какое место в верлибре и переходных формах занимают другие форманты, но заметим: ориентация на верлибр не дает достаточного материала для постижения природы стиха.

Наибольшую путаницу в теорию стиха внес феномен В. Маяковского. Из всех перипетий многолетней дискуссии вокруг френомена нас интересует лишь один эпизод полемики школы Л. И. Тимофеева в лице Б. П. Гончарова с группой А. Н. Колмогорова. Колмогоров и ученики произвели детальный лингвостатистический анализ произведений поэта, выделив несколько типов «тонического» стиха (Колмогоров \& Кондратов 1962; Кондратов 1962; Колмогоров 1963; Колмогоров \& Прохоров 1964; Колмогоров 1965). Но при этом графическое членение - знаменитая «лестница Маяковского» - ими не бралось в расчет, что и вызвало возражения (Гончаров 1970; Гончаров 1972). Согласно интонационной теории Тимофеева семантические паузы - один из важнейших формантов стиха, а «лестница» как раз и была их графическим эквивалентом, поэтому, по мнению Б. П. Гончарова, А. Н. Колмогоров и М. Л. Гаспаров (Гаспаров 1965; Гаспаров 1967) грубо исказили природу объекта. Подобные сомнения появились и со стороны Г. М. Печорова (см. Печоров 1970; Печоров 1971), трактующего стих Маяковского как «синтагменный». Не углубляясь в содержание дискуссии, заметим, особенно странно такое невнимание выглядит со стороны М. Л. Гаспарова, для которого графическое членение служило ultima ratio при интерпретации верлибра как стиха. Однако ни Б. П. Гончаров, ни 


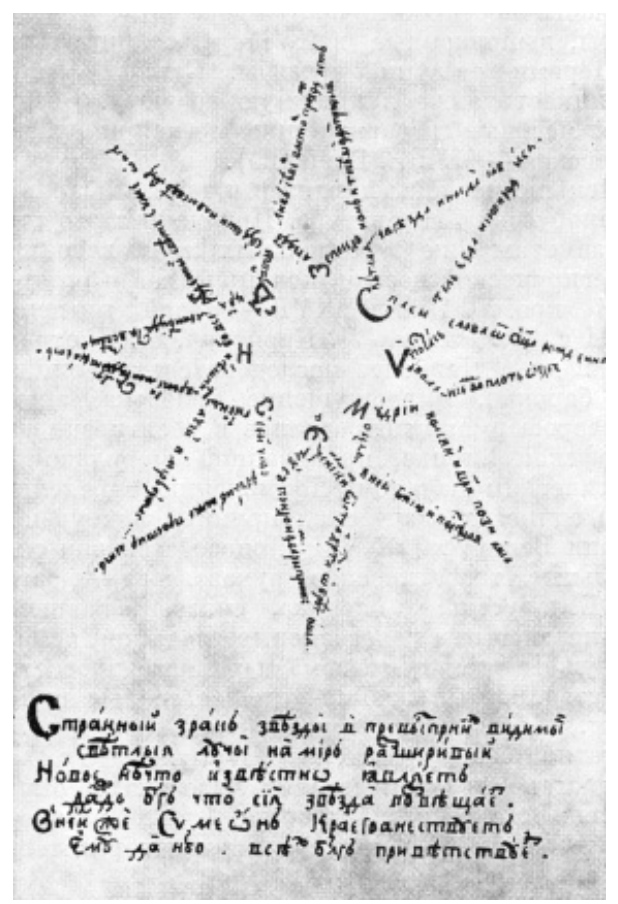

Симеон Полоцкий. Стихотворение в форме звезды.

Г. М. Печоров так и не объяснили, в чем же стиховая специфика «пауз" и «синтагм», к которым они апеллировали. Мы считаем, что эти интерпретации не антагонистичны: стих Маяковского основывается на контрасте двух рядов: вербального и графического. Причем последний в большей степени диссимметричен и тем самым приближен к прозе.

В принципе, можно допустить, что проза, разделенная на строки, как вода в вино, превращается в стих. Но задумаемся, что же происходит при обратной процедуре, когда правильный стих, написанный строгим размером с рифмой, автор разбивает на асимметричные строки? После В. Маяковского многие советские поэты производили подобную операцию. У Маяковского за 


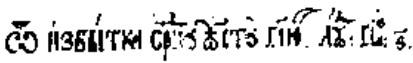

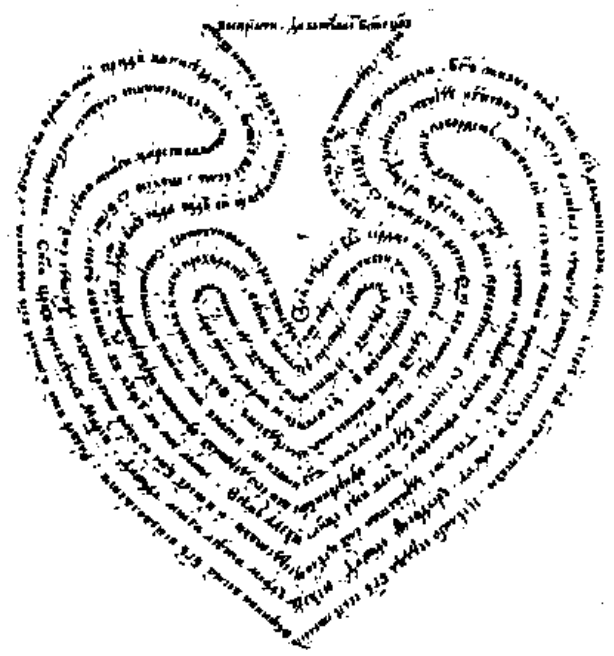

Симеон Полоцкий. Стихотворение в форме сердца.

графикой вскрываются еще и регулярные отклонения вербальной структуры от метрики (или наоборот - рефлексы метрики в дисметричном стихе). Но у его последователей вербальный ряд часто вполне традиционен, что упрощает разграничение различных рядов.

Рассмотрим отрывок из Дануты Бичель, имеющий подобное вторичное членение (АЖП: № 14):

Тваіх

маёвых вуснаў

цеціва

з маёвымі суніцамі

у хаўрyce.

Ты

мог бы імі

зацалаваць

усіх жанчын вясновай Беларусі. 
Если оформить эти строки классически, без вторичного членения, то явится четверостишие, написанное пятистопным пеонизированным ямбом (с одним небольшим отклонением):

Тваіх маёвых вуснаў цеціва

з маёвымі суніцамі ў хаўрусе.

Ты мог бы імі $\wedge$ зацалаваць

усіх жанчын вясновай Беларусі.

Пеонизация - сильное средство усиления симметрии на стопном уровне, которое придает стиху безупречную размеренность и благозвучие. Вряд ли разбивка стихов на мелкие диссимметричные строки, разделение строфы на два строфоида усилили напевность. Разве что сделали отрывок интонационно более выразительным. Но при чем здесь стих? Выразительность интонации необходима и прозе. Единственное оправдание вторичного членения может быть в том, что таким образом камуфлируется потеря одного слога в третьей строке, причем именно на пеоническом икте, который не допускает не только пропусков слогов, но даже отсутствия акцентов. Конечно, лейма на структурно значимом месте вызывает диастолу (интенсу) на приставке за- следующего слова, что компенсирует потерю икта. Но где здесь причина, где следствие - сказать трудно. Скорее всего, поэтесса не заметила потери, не придала ей веса, так как сегмент зацалаваць, поставленный в контекст ямбических строк, выглядит, как нормальная строка двустопного ямба. Значит, графическое членение, как бы мы к нему ни относились, будет фрактором разрушения общей метричности при локальной ее компенсации.

Возьмем еще один пример из малоизвестной поэтессы 1920-х гг. Ганны Брестской (АЖП: № 11):

Над зялёнай

Над палянай

Заблудзіўся

Месяц п’яны,

I туман сінявалосы

Распусціў

Густыя косы,

Косы лёгкія, як дым.

А гармонік

Грае, грае, 


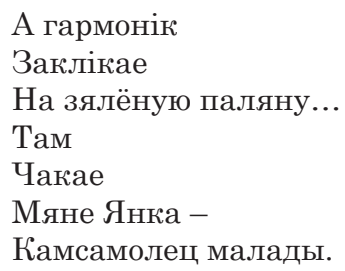

Отмена диссимметричной графики и сближение графического контура текста с симметрией вербального ряда открывает в этом стихе интересный порядок рифмовки и альтернанса, что позволяет трактовать фрагмент как 10-сложную строфу:

\section{Над зялёнай над палянай \\ Заблудзіўся месяц п’яны, \\ І туман сінявалосы \\ Распусціў густыя косы, \\ Косы лёгкія, як дым. \\ А гармонік грае, грае, \\ А гармонік заклікае \\ На зялёную палян[к]у... \\ Там чакае мяне Янка - \\ Камсамолец малады.}

Несомненно, мы далеки от того, чтобы нарушать авторскую волю или доказывать, будто один способ оформления лучше другого. Это лишь опыт сравнения разновидностей графики, раскрывающий ее отношение к вербальному ряду.

Изредка поэты записывают стихи прозой, в белорусской литературе к такой записи один из первых обратился забытый поэт начала XX в. Василь Василек (HН: 1):

Як жа хораша вясною | | на Цябе дзівіцца, | | какалуша

Ты зялёна... || Любіш, ах, квяціцца...

Интересно заметить, что метрическая структура в записи прозой даже быстрее мысленно воссоздается, чем при асимметричной графике. Данное явление М. Л. Гаспаров называл «мнимой прозой» (Гаспаров 2004: 21), уже само название говорит о том, что членение на строки, каким бы важным оно ни было, не определяет вербальной структуры стиха. Здесь Гаспарова можно упрекнуть за «двойную бухгалтерию» - один критерий для верлибра, другой - для «мнимой прозы». Получается, графика, как и распевание текста, еще не показатель стихотворной формы. 
Стихотворение Василька написано одним из популярнейших размеров, трактуемым в литературе как сочетание четырехи трехстопного хорея, а в фольклоре - как 8+6 (или 4+4+6), в силлабике, иногда, - как 14-сложник. Обычно этот размер фрольклористы записывают в виде четверостишия, реже - двустишия. Максим Богданович свое подражание народному стиху оформил в две строки (Б.: 120):

У Максіма | на кашулі || вышыты галубкі;

Я за тое | вышывала, | | што цалуе губкі.

А в более раннем, не стилизованном, хотя тоже ориентированном на фольклор произведении, поэт употребил размер как четверостишие (Б.: 30):

Месяц круглы | ўстаў на небе,

Блішчыщь невысока,

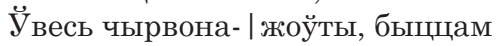

Пугачова вока.

Но классическая запись этого размера, как известно, имеет форму «елочки», например, в стихотворении Янки Купалы (Кп. 1: 76):

Зашумеў лес | разгуканы, Нівы задрыжалі,

Задрыжалі | і тыраны, Што бяду стваралі.

Можно привести и более редкий образец того же размера в «скошенной», или «ступенчатой», графике, примененный Верой Мурашкой (АЖП: № 12):

$$
\begin{aligned}
& \text { Ціха ў цәлі | маёй душнай, } \\
& \text { Спіць пануры дом. } \\
& \text { За дзень цәлы | пасля гора } \\
& \text { Пазабыўся сном. }
\end{aligned}
$$

Все эти графические формы так или иначе подчеркивают симметрию и асимметрию вербального ряда, поэтому проясняют метр, хотя ступенчатая форма - уже избыточна для метра. А проясняется ли метр в стихотворении Андрея Александровича (А.: 319):

Заспявалі

Сталлю

Змеі - 


\section{Магістралі}

Рэек

- сказать затруднительно. Скорее подчеркивается значимость каждого слова, но интонация здесь в конфоликте с метрической структурой. Этот фрагмент в классической записи выглядел бы так:

\section{Заспявалі | сталлю змеі -}

Магістралі рэек.

А четырех- и трехстопный анапест (ряд примеров из которого мы выше рассмотрели) в диссимметричной графике Александровича вообще нелегко распознать без специального метрического анализа (А.: 48):

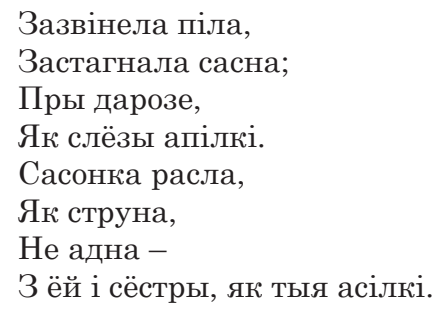

Примечательно, что Александрович, широко применявший модную в 1920-е гг. диссимметричную графику, на деле пользовался традиционными размерами, большинство из которых применялись еще в газете "Наша Ніва» (что свидетельствует о зависимости модернистов от ритменных стереотипов своего времени). Однако нельзя сказать, что графика вообще не влияла на состояние стиха. Александрович позволял себе намного больше вольностей и аномалий, которые не встречались у предшественников. Среди правильного анапеста в отрывке один из колонов - Сасонка расла - амфибрахический, то есть, как и в строке Бичель, здесь не хватает одного слога, что можно назвать спорадической прозаизацией. Но для прозаизации стиха даже потери слогов необязательны. Ведь не сразу можно догадаться, что следующие строки - не верлибр, а пятистопный хорей (А.: 173):

Бар.

Бульвар.

Рамізнік.

Прастытутка.

Купля. Продаж. Мена.

Змрок і чад. 


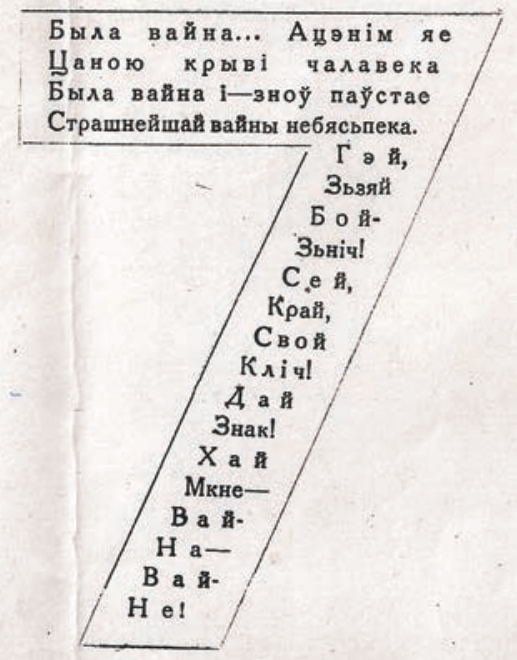

1 у прыбоях навальнічых

Сьмерџь вайне прынёс Кастрычнік.

Андрей Александрович. Стихотворение в форме семерки.

Что же происходит на деле при вторичном диссимметричном членении симметричной вербальной структуры? Прозаизация? Или вообще ничего не происходит? В любом случае, «стиховность» таким образом не возрастает. Если ничего не происходит, то, получается: членение на строки не является конструктивным моментом стиха. А если все же - прозаизация, то налицо парадокс: одно и то же действие, членение на строки, прозу превращает в стихи, а стихи приближает к прозе. Выходит, не всякая дополнительная сегментация делает стих стихом, членение на строки - это только внешнее проявление чего-то более существенного.

В рассмотренных фрактах нет ничего принципиально нового, каждому, имевшему дело со стихами, эти примеры могут пока- 


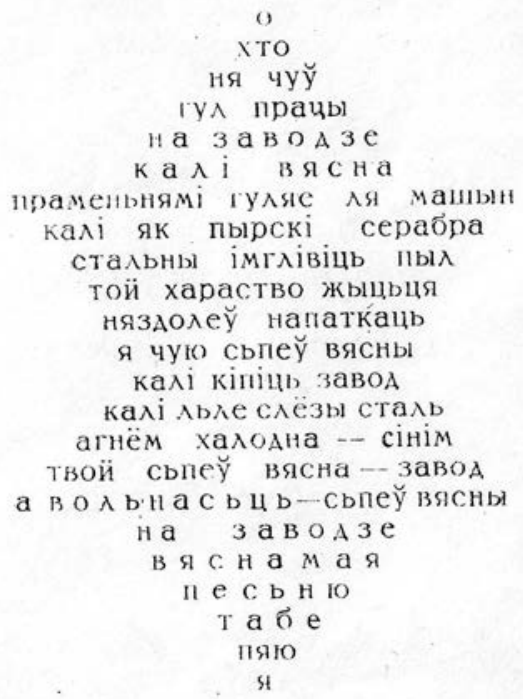

Андрей Александрович. Стихотворение в форме звезды.

заться тривиальными. Поэтому и следующий вывод Б. В. Томашевского, высказанный в 1950-е гг., должен казаться вполне очевидным: «Мы оперируем чисто графическими образцами. Воображая стихи, мы представляем себе текст, разбитый на строки. [...] нам необходимо освободиться от графических представлений» (Томашевский 1959: 15). Этот имеет важное методологическое значение для фольклориста. Но, оказывается, не для всех очевидно. Томашевский был бы, наверное, удивлен, узнав, что стиховедческая теория двинется в обратную сторону (и именно в лице наследников формальной школы, можно сказать, учеников его учеников). Ю. Б. Орлицкий, исходя из популярного положения М. Л. Гаспарова, что в дописьменный период тексты делились не на стих и прозу, а на произносимые 


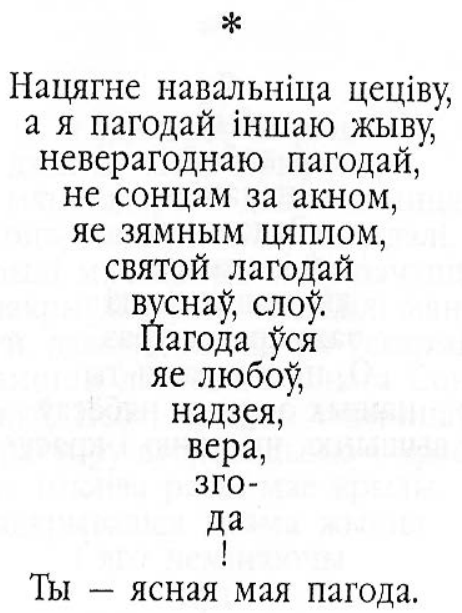

Василь Жукович. Фигурное стихотворение.

и поющиеся, сделал вывод относительно устного творчества: «С точки зрения предлагаемой типологии и та и другая не могут рассматриваться как стихи или проза сами по себе, но неизбежно становятся стихом или прозой, обретя ту или иную конкретную форму письменной фиксации: поющиеся жанры как правило «превращаются» в стихи, произносимые - в прозу» (Орлицкий 2008: 26).

Даже и не скажешь сразу, радоваться фольклористу по такому случаю или застрелиться. Ведь членение на строки - это интерпретация публикатора, которая может реализоваться в различных версиях, поэтому строка - единица нерелевантная для фольклора, о чем мы писали неоднократно (Пацюпа 2016; Пацюпа 2017: 655). Если всерьез отнестись к словам Ю. Б. Орлицкого, то стиховед-фольклорист обязан стать заложником всех непоследовательностей эдиции, и изучать все графические интерпретации текста как объективные фракты, - фракты неизвестно чего. Не устного творчества, потому что на него наложено 
вето, и не литературы, потому что записанный фольклор все же не литература. Неужели не понимает опытный филолог, что при таком подходе невозможна никакая типология, так как одна и та же форма может иметь несколько графических реализаций, которые ни о чем не свидетельствуют? Если в литературе графика выражает по крайней мере эстетическую позицию автора, то в фольклоре не выражает ничего собственно фрольклорного.

Чтобы не быть голословным, рассмотрим графические версии жнивной песни 4+6+6+(4). Если всерьез ориентироваться на «строки», то одну версию можно трактовать как четверостишие из двустопного и трехстопного хорея и его зеркального отражения - трехстопного и двустопного (ПЗК: 347 ):

$$
\begin{aligned}
& \text { Ай, дабранач! } \\
& \text { Шырокае поле, } \\
& \text { Жыта ядраное, } \\
& \text { Ай, дабранач! }
\end{aligned}
$$

В иной графике комбинация 4+6+6+(4) выглядит как полиметрическая трехстрочная строфа, где первая «строка» - пятистопный хорей, вторая - трехстопный, а третья - двустопный (ПЗК: 378):

Павілося бела павучынне

Па чысценькім полі,

Павілося.

В действительности это тот же размер, и переписать его можно в виде уже знакомого нам четверостишия:

$$
\begin{aligned}
& \text { Павілося } \\
& \text { Бела павучынне } \\
& \text { Па чысценькім полі, } \\
& \text { Павілося. }
\end{aligned}
$$

Но ничто не мешает оформить его и в виде двустишия пятистопного хорея:

Павілося бела павучынне

Па чысценькім полі, павілося.

Аналогичные случаи в фольклорных сборниках исчисляются сотнями, иногда - на одной странице, как результат работы различных фольклористов. Графические интерпретации ничего не меняют в структуре народных песен, как ничего не меняло 
рассаживание героев в басне Крылова «Квартет», в песнях есть нечто более стабильное, чем случайно оформленные «строки».

\section{Отношение стиха к читке}

Экспансия графических форм в пределы устной речи случалась не раз, в этом нет ничего удивительного. Однако важно выяснить, почему сегодня в стиховедении она так настойчиво и так уверенно проводится. Ведь на самом деле, если взглянуть на дилемму с позиции здравого смысла, то положение Б. В. Томашевского о несводимости вербального ряда к графическому вполне резонно. В то время как обратное ему утверждение Ю. Б. Орлицкого доводит до логического абсурда графическую тенденцию, тем самым упрощая работу оппонентов. Однако со времен Парменида и Зенона из Элеи уход от здравого смысла не только не смущал теоретиков, но даже провоцировал на самые парадоксальные выводы, поэтому апелляции к здравому смыслу мало, нам необходимо произвести небольшую деконструкцию графического уклона.

Уклон в графику имеет свою предысторию и возникает не столько под влиянием верлибра, сколько в борьбе с декламационными и музыкальными теориями стиха. Первый этап критика в 1920-е гг. «слуховой» филологии Э. Сиверса, согласно которой предмет традиционной «зрительной» фрилологии - это только «жалкий суррогат» живого слова. Основные моменты полемики раскрываются в предисловии к работе Б. М. Эйхенбаума «Мелодика русского лирического стиха» (Эйхенбаум 1969: 333348). Если сторонники Сиверса утверждали, что не глаз, а ухо инструмент изучения стиха, то их противники возражали, мол, надо не только уметь слышать, но и уметь читать глазами, «как музыканты читают партитуры» (там же: 335). Нельзя также забывать, что «слуховая» филология возникла до появления фонологии и до того, как распространились идеи Ф. де Соссюра, чем и объясняется абсолютизация звучания как такового. Требование разграничивать стих и декламацию стало чуть ли не аксиомой науки о стихе, однако до отождествления стиха и его графики формалисты не доходили. Когда Ю. Н. Тынянов писал: «некоторые существенные фракты поэзии не исчерпываются акустическим обнаружением стиха и даже противоречат 
ему» (Тынянов 1965: 43), то не было и речи о сведении стиха к графике, а лишь об ограничении претензий акустического подхода и признании за графикой самостоятельного значения.

Вторая волна антидекламационных настроений зародилась в 1960-е гг. после публикации новых работ А. П. Квятковского. Не стоит задерживаться на содержании полемики, заметим лишь, оппоненты Квятковского не всегда понимали, что критикуют. В. Е. Холшевников настаивал: «Ритм стихов - не музыкальный, а речевой» (Холшевников 1987: 6). М. Л. Гаспаров постоянно писал: «Декламационные признаки не могут характеризовать место размера в системе стихосложения» (Гаспаров 1974: 299). А все-таки, музыкальная или декламационная теория Квятковского? Значительно позже И. Б. Роднянская, защищая своего учителя, ответила на этот вопрос: «Теория Квятковского за время своего становления [...] превратилась из “произносительной” в структурную и получила завершение именно как таковая» (Роднянская 2008: 680). К сожалению, ее эволюции никто не заметил. Но, если есть неудобная теория и нет желания всерьез полемизировать, тогда просто навешивается ярлык. Гаспаров меньше, чем кто-либо другой, критиковал Квятковского, но никогда не уставал повторять: это теория не стиха, а декламации и полагал, будто тем самым вопрос закрыт. Нас в данном контексте не интересуют все ошибки Квятковского, а их у него множество, как, впрочем, и открытий, но характер некоторых ошибок - прежде всего неоправданное нагромождение лейм в схемах стиха - вызвал недоверие к акустическому методу.

Не было бы ереси - не было бы и догмата. Как арианство подтолкнуло католическую церковь на введение догмата Filioque, так и ритмология А. П. Квятковского спровоцировала антидекламационную установку как обратную крайность. В принципе, опасность декламационных и музыкальных теорий существует, нельзя путать текст и способы его исполнения. Но стих - это все же динамическая система, и если мы говорим о ритме как порядке ударений, то имеем ввиду не фикцию и не абстракцию. Более того, мы знаем, что это не просто ударения отдельно взятых слов, а ударения, возникающие в речи (в колоне, периоде, строке), у них есть законы, пожалуй, отличные от законов прозы. Наконец, необходимо различать д ек л а м а ци ю и рецитацию, иначе теоретическая модель стиха превратится в механическое соединение словарных единиц. Не стоит 
даже напоминать, насколько важна рецитация для понимания метрики и сколько к ней апеллировали представители самых разных школ. К сожалению, в практике новой волны русского стиховедения, начиная с 1960-х гг., «глухой метод», т. е. метод лингвостатистики, свел все живые наблюдения над материей стиха почти к нулю. Б. В. Томашевский, один из отцов-основателей статистического метода в стиховедении все же не замыкался на статистике и часто обращался к приему, который В. Чудовский называл «методом вслушивания».

На фоне дегуманизации методов стиховедения гаспаровский «парадокс очевидного», что в дописьменную и даже раннеписьменную эпоху вместо оппозиции стих / проза существовала оппозиция поющееся / произносилое (Гаспаров 2000: 21), стал миной замедленного действия, взорвавшей, в конце концов, наивные представления. Это, в свою очередь, спровоцировало новые парадоксы. При этом никто не заметил, как структурный подход подменили функциональным, а вненаходимость аналитика позицией пользователя. Даже возник спор об авторстве парадокса: «Эта идея относительно релевантности для русской средневековой литературы оппозиции «песенное / разговорное» была высказана Ю. М. Лотманом еще в 1964 году и лишь потом получила развитие и дальнейшее обоснование в работах М. Л. Гаспарова» (Руднев 1989: 51). Странно, что П. А. Руднев не заметил этой идеи у А. Н. Веселовского (на которого страницей ранее ссылался): «Исторически поэзия и проза, как стиль, могли и должны были появиться одновременно: иное пелось, другое сказывалось» (Веселовский 1989: 296). А. Н. Веселовский, однако, не делал из данного фракта радикальных выводов, понимая, видимо, что вещь и восприятие вещи не совсем одно и то же.

Оппозиция поющееся / произносилое существует издавна, но далеко не всегда применима как эквивалент отношения cтux / проза, ведь прозу можно петь, а стихи рассказывать. Для Веселовского важно было уяснить момент зарождения стиха, не более того. Применение этой аналогии в сравнительно позднем контексте вообще сомнительно, в лучшем случае гипотетично. Оно понадобилось М. Л. Гаспарову для оправдания трактовки стиха как текста, записанного "в столбик», так как в эту теорию не вписывался устный стих, благо, он пелся. Но и здесь не для всех случаев верно утверждение Гаспарова, что «членоразделы» в народной песне «заданы напевом» (Гаспаров 2000: 22), есть 
же случаи «несовпадения мелодической и поэтической цезур» (Руднева 1994: 34), и «не всегда музыка подчеркивает строфное строение песни: это задача текста» (Елатов 1966: 55). Как в стихотворстве вербальный ряд не сводится к графике, так в фольклоре - к мелодике. Но нас здесь интересует иное значение оппозиции, к нему и вернемся. И прежде всего - к чтению, которое выполняет не только коммуникативную и эстетическую функции, но и гносеологическую, так как моделирует ритм, который осуществляется в речевом акте. Преимущество пения в том, что оно представляет наиболее полное, «окончательное» решение фольклорного текста, а чтение - только предварительный набросок, но в этом наброске легче наблюдать структурные моменты ${ }^{16}$, скрытые в пении.

О применении читки при изучении ритмики народно-песенной поэзии есть интересное рассуждение А. Х. Востокова: «Основа сия [ударений] столь ощутительна при чтении стихов, кои, конечно, для пенья собственно, а не для чтенья сочинены, в одно время с их голосами! Не берусь изъяснить сего противуречия между мелодиею и прозодиею русских песен, но оно существует; и природа, единственная учительница русских стихосложению, умела согласить независимое существование в русском стихе двух разных мер, т. е. пенья и чтенья» (выделено нами, - Ю. П.) (Востоков 1817: 156-157). Здесь речь идет о «чтенье», имеющем меру, о «чтенье» как методе прояснения ритмических особенностей текста, иными словами - о рецитации. Позже к такому же выводу пришел и А. П. Квятковский: «Я убежден и утверждаю, что для выяснения метрического или дисметрического строя народного стиха [...] не только не обязательно знать его песенный ритм, но и вовсе не нужно привлекать его» (Квятковский $\&$ Колмогоров 2008: 32). Следует обратить внимание, что оба, и Востоков, и Квятковский, дистанцируются от музыкальных теорий стиха и сходятся на рецитации как альтернативе ей.

Конечно, Востокова можно списать на архаику, а Квятковского отнести к разряду декламации, но тем самым вопрос не снимается. Какой тогда ритм изучается статистическом методом, если его невозможно материализовать? Фонетика и фонология в большинстве школ, кроме глоссематики, так или иначе между собой связаны. Конечно, стиховедение может выбирать любой ориентир, в том числе и глоссематику, этому нельзя противиться. Но это и не основание, чтобы считать нерелевантными 
исследования, опирающиеся на нечто более конкретное. Впрочем, глоссематика основывается на дедукции, а стиховедение, которое в каждой читке видит декламацию, - индуктивное и эмпирическое от начала и до конца и не склонно к обобщениям. Почти все понятия в его арсенале - заимствованные: классические (ямбы, хореи) или созданные «декламаторами» (дольники, тактовики). К ним лишь прилагаются - тщательные статистические выкладки. И классические и новые категории - довольно спорные, но верифицировать их можно лишь с помощью рецитации - «методом вслушивания». Иначе говоря, эмпирически, но не разъяв текст на атомарные лексемы или вокабулы, а в динамике стихотворной речи.

Если Востокова или Квятковского можно нейтрализовать, не вступая с ними в полемику, то Б. М. Эйхенбаум стоял у истоков антидекламационного направления и не считаться с его выводами труднее. А именно у него мы находим важнейшие положения, обосновывающие рецитацию как методику изучения стиха без уклонения в декламацию и в графику. Б. М. Эйхенбаум сформулировал три основных правила применения рецитации: 1) «природа стиха (особенно лирического) органически связана с произносительно-слуховыми моментами» (Эйхенбаум 1969: $342), 2$ ) «прежде чем исполнять, надо уметь читать» (Там же: 340) и, наконец, 3) «дело, конечно, не в чтении вслух, а в самом слуховом принципе» (Там же: 335). Если стиховедение и дальше будет игнорировать слуховой принцип или, как это повелось в последнее время, вести с ним войну, то навсегда потеряет связь с поэтической практикой. Впрочем, и сама практика может быть механическим копированием готовых образцов или даже апофеозом ритмической глухоты. Симптоматичны в этом смысле слова Д. Давыдова: «Поэзия пошла во многом по неутешительному для Квятковского пути и произносительные критерии подчас оказываются неработающими» (Давыдов 2008: 709). Но что такое те несколько десятилетий против веков классической литературы и тысячелетий фольклора, даже если бы поэзия исчезла как вид искусства?

Оппоненты А. П. Квятковского, борясь с декламационными уклонами, рискуют подсечь сук, на котором сидят, вслед за декламацией под вопросом должна оказаться и скандовка как разновидность читки. Но в 1920-е гг. после кризиса метрики 1910-х гг. теория интенс Г. А. Шенгели и теория скандовки 
Б. В. Томашевского худо-бедно, но спасли метрику (Бухштаб 1969: 386-393). Первая, основанная на рецитации, не была поддержана стиховедами, вторая же стала почти единственным объяснением метрики. Вот как ее применение обосновывал автор: «Конкретная метрическая система [...] с ясностью обнаруживается не в нормальном чтении стихов, не в декламации, а в особом чтении, проясняющем закон распределения ударений, в скандовке. [...] Она неизбежно сопутствует нашему восприятию стихов [...] и определяет собою характер произнесения стихов, столь отличный от произнесения прозы и именуемый декламацией» (Томашевский 2008: 31-32). И если скандовка средство более насильственное, чем рецитация, все же проясняет метр, то полезного эффекта следует ожидать и от более мягкого средства. Скандовка, унифицируя ритм, верифицирует метрику, рецитация же индивидуализирует каждый конкретный случай и тем самым диагностирует вариации ритма. Первая полезна в обучении, или, как говорил Томашевский, в «поэтическом воспитании», вторая - в науке, при исследовании ритмического процесса.

Итак, есть три основные разновидности чтения поэтических текстов: скандовка, рецитация и декламация. Декламация, в свою очередь, делится еще на два подвида: н а п е в ную , читку, свойственную поэтам, и рито р ическую, распространенную среди актеров.

Чем отличаются скандовка, рецитация и декламация, можно показать на примере четверостишия Якуба Коласа. Проскандируем его, то есть прочтем так, как читаются детские считалки (Кл.: 275):
Дружа!| Кінь на| неба| вока -
Колькі| зорак,| колькі| зор!
Як пры|вольна, | як да|лёка
Ззяе, | свеці | цца пра | стор!

Такая читка выглядит неестественно. И не только потому, что в слове свеціциа допущены два акцента, просто, так никто не обращается со стихами к аудитории, а тем более не читает "для души». Зато мы смогли убедиться, что четверостишие написано безупречным четырехстопным хореем, здесь не только почти все стопные ударения в наличии, но даже в первой и второй строке стопы выделены диерезами. 
А теперь изберем монотонный темп рецитации и прочтем отрывок так, как читают нерадивые школьники и некоторые поэты - без интонационных модуляций, и с упором на такты:

Дружа! КІнь на неба вОка -

Колькі зОрак, колькі зОр!

Як прывОльна, як далёка

Ззяе, свЕціцца прастОр!

На этот раз читка выглядит нормальной, хотя и не художественной, в ней все строки формально уравниваются и выделяются опорные акценты, без которых нельзя воспроизвести ритм данного размера. И, что существенно, - эти акценты не подставные, как в слове свеціциа на слоге -циа, а реальные. Опорные акценты образуют уже не хорей, а нечто иное - то ли сквозь хорей проступает пеон третий, то ли стопы хорея соединяются в диподию. Как это правильно называть - пока несущественно, но отрицать особый ритменный статус каждой второй стопы невозможно. Опорные икты - такты - реально существуют и для них нет ритменной альтернативы. Мы не сможем, даже если и захотим, выделить в качестве тактовой другую пару стоп, скажем, первую и последнюю, можем только вернуться к скандовке и выделять стопы все подряд, без исключения. Исходя из этого факта, можно понять, почему А. П. Квятковский настаивал, что «в основе ритмики ямбов и хореев лежит четырехдольная мера" (Квятковский 1966: 96).

И, наконец, испробовав скандирование и рецитацию, продекламируем четверостишие Коласа в такой манере, которую называют «выразительным чтением», выделяя интонацией все смысловые оттенки:

$$
\begin{aligned}
& \text { ДрУжа! } \\
& \quad \text { КІнь на неба вока - } \\
& \text { КОлькі зорак, } \\
& \text { кОлькі зор! } \\
& \text { Як прывольна, } \\
& \text { Ззяе } \quad \text { Як далёка } \\
& \text { свеціцца } \\
& \quad \text { прастор! }
\end{aligned}
$$

При графическом оформлении декламации мы сразу же должны были пожертвовать симметрией строк, так как семантические 
акценты здесь, как и в прозе, выделяются без учета ритма, но вместе с ритмическими акцентами образуют одно целое. При этом нельзя утверждать, что предложенная версия декламации единственно правильная, что у нее нет альтернативы. А если так, то понятно, почему ориентация на декламацию приводит к субъективизму в интерпретации ритма. Следует заметить, в декламационной интерпретации актуализируются не только пеонические икты, но и остальные хореические, когда на них падает эмфатическое ударение. А это значит, А. П. Квятковский не совсем был прав, категорически отрицая двудольную меру. В декламации слабые икты актуализируются по мере их востребованности, а сильные могут ослабляться, но не атонируются, все вместе они задает игру ослаблениями и усилениями, богатую потенциями, которых, кстати, не бывает в трехсложных размерах, более монотонных по своей природе.

Итак, скандовка, рецитация и декламация различаются не только как стили произношения, но и утилитарно. Функция скандовки - формальный счет стоп, рецитации - диагностика ритма и его аномалий, а декламации - репрезентация содержания. Для формального исследования стиха значимы лишь скандовка и рецитация. При этом рецитацию нельзя свести к скандовке в ритме пеона (хотя, в принципе, и такая существует), так как в рецитации учитываются лишь реальные акценты, а не потенциальные, как в скандовке.

В коласовском четверостишии все опорные пеонические икты стоят на своих местах, поэтому рецитация почти не отличается от скандовки, но уже ямб Максима Богдановича в рецитации имеет отличия по сравнению со скандовкой (Б.: 17):

Блішчыць у нЕбе зор пасЕў;

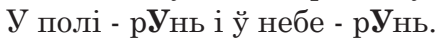

Да рЭчкі лецячы, ўзляцЕў

Між імі мАрай белы лУнь.

При рецитации третья строка здесь так выбивается из общего размера, что не заметит это лишь человек глухой к ритму. Все строки, кроме третьей, рецитируются как пеонические, а третья - как гексоническая ${ }^{17}$. Такой эффрект возникает из-за отсутствия акцента в позиции сильного икта. Ничто не может разрушить каркас пеона - ни заполнение или незаполнение ударениями остальных позиций, ни словоразделы, - ничто 
кроме отсутствия акцента на четвертом слоге. И в то же время - все четыре строки скандируются, как ямб. Выявить среди ямбов-пеонов ямб-гексон можно лишь с помощью рецитации. Не поможет в этом ни скандовка, которая унифицирует ритм, ни декламация, позволяющая усиливать икты па вкусу, независимо от их позиционного статуса. Например, в строке ДрУжа! / Кінь на неба вока слово дружа мы выделяли, чтобы подчеркнуть обращение, хотя могли и не выделять, а в строке Да рЭчкі / лецячы, уззляцеу слово да рэчкі не могло не выделяться, так как в слове леиячьі не хватает тактового (или пеонического) ударения не -ле.

С помощью рецитации мы доказали, что ударения в строке несводимы к ударениям лексем или вокабул, а имеют позиционные характеристики. Но не только в позиционных различиях дело, есть в стихе и контекстуальные ударения, что можно наблюдать на примере из Феликса Топчевского (Хр.: 324):

На Тройцу, звЫчай як у свЯта, Пад'еў і ўздУмаў с а б е спАщь, Аж чую, з А г а м н н і у тАта: "Ідзі пчол пАнскіх пільнавАць!"

Ямб Топчевского, как и других белорусских поэтов XIX - начала $\mathrm{XX}$ вв., насыщен инверсиями ритма. Правда, в отрывке инверсия на слове сабе почти незаметна, так как находится на самой слабой стопе - перед константой - да еще и на местоимении. Зато словоформа загаланіу охватывает целых две стопы, и ее реальный акцент на слоге -ніў не может не атонироваться, так как занимает метрически слабое место, да еще и рядом с константой. А между тем приставка за- оказалась именно там, где должен находиться опорный пеонический икт, и, естественно, такое противоречие не может не вызвать контекстуального ударения (или по Г. А. Шенгели интенсы) на приставке. В терминах В. Брюсова можно сказать так: систола на -ніў вызвала диастолу на за-. Третья строка, и у Богдановича, и у Топчевского, структурно схожи, но у последнего присутствует инверсия и это принципиально меняет ситуацию - по сути, восстанавливается пеон там, где у Богдановича был гексон. Интенса - довольно редкое явление в двусложных размерах, на слабых иктах она и вовсе не нужна, а на сильных - чаще всего происходит транспозиция тактов, превращающая пеоны в гексоны. Конечно, 
в декламации можно разными способами игнорировать то, что есть в рецитации, как в рецитации постоянно игнорируется то, что есть в скандовке, но это ничего не доказывает, стих, в конце концов, можно читать и как прозу.

Заметим, сильные (или опорные, пеонические, тактовые ${ }^{18}$ ) икты - это не обязательно те, которые сильнее произносятся, и не всегда статистически самые частотные, а те, утрата которых ведет к радикальному изменению ритма строки, как в примере из Богдановича. Заметить этот эфффект можно лишь с помощью рецитации, так как статистика глуха к ритму и дает нам то, что мы хотим: обращаемся к ямбо-хореической шкале - имеем статистику ямба или хорея, если обратимся к пеонической шкале - получим статистику пеонов в том же тексте. Естественно, значимость позиции ведет и к более частому ее заполнению (явление регрессивной акцентной диссимиляции), и к более интенсивному произношению икта при рецитации, но и громкость и частотность - характеристики акцидентальные, не атрибутивные - результат локализации ударения в определенном месте строки.

Возвращаясь к сказанному, следует заметить, графика всетаки ближе к декламации, чем к вербальной структуре стиха, между ними больше общего, чем между стихом и графикой, стихом и декламацией, и та и другая зависят от вкуса автора или исполнителя стихов. Графика и декламация могут быть симметричны, асимметричны или диссимметричны, в одном случае больше стиха, в другом - прозы. Конечно, вербальная структура стиха тоже может быть диссимметричной, на одном или нескольких уровнях, но это и есть то, что называется прозаизацией. В идеале стих и проза противостоят именно как симметрия и диссимметрия, чем больше симметрии, тем больше стиха - и наоборот. Не только вещественные слоги, акценты, но и невещественные паузы (к которым апеллировала школа Тимофеева) ничего специфически стихового не несут в себе, если не включены в организацию симметрии ${ }^{19}$. По отношению к графике еще следует сказать, что она не пронизывает текст как иерархическое целое сверху донизу, а охватывают лишь один, максимум - два уровня, прежде всего - строку, где сочетаются колоны и периоды. Это значит, она - не органическое свойство стиха. Сказанное М. Л. Гаспаровым о декламации с тем же, 


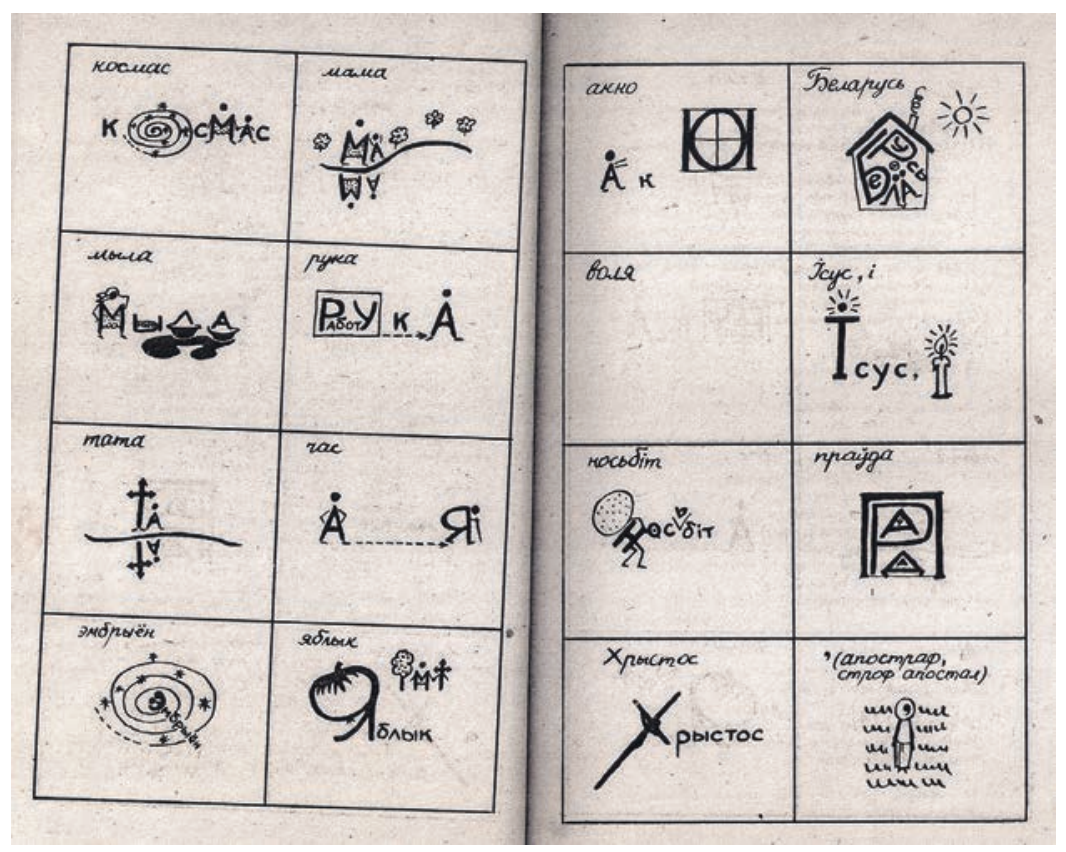

Людка Сильнова. Рисословы.

и еще большим, основанием можно отнести к графике: «Речь здесь идет о свойствах не заложенных в стихе, а привносимых в стих» (Гаспаров 1974: 299).

Градический уклон приводит к парадоксам, что часто свидетельствует о ложности теории. Многие традиционные характеристики стиха, такие, как метр, рифма выглядят в этом случае факультативными, зато вертикальная графика, которую можно встретить и в каталогах, и в афишах - объявляется едва ли не главным отличием стиха от прозы. По словам Ю. Б. Орлицкого, «не нарушая общей идеи реальной дихотомии стиха и прозы, мы вынуждены говорить...» о фольклорном стихе, как «о текстах, которые невозможно корректно интерпретировать как стихотворные или прозаические [...] в силу их неписьменной природы» (Орлицкий 2008: 29). Получается, что меню в ресторане, афиша, записанная столбцом, - более стихи, чем народная 
песня, которая никогда не записывалась, а записанная - она сразу же превращается в стих, так же, как в эксперименте М. Л. Гаспарова превратился в стих абзац статьи. (Правда, там все-таки речь шла о верлибре.) Парадоксально? Но все это не придумано нами, а если что-либо и додумано, то «не нарушая общей идеи реальной дихотомии».

Однако, как только Орлицкий обращается к «мнимой прозе», он, как и М. Л. Гаспаров, изменяет своему ultima ratio и пишет о подобных текстах: «В них присутствуют все традиционные вторичные признаки стихотворной речи: отчетливый силлаботонический или дольниковый метр, изотония, изосиллабизм, регулярное чередование клаузул, рифрма, строфрическая регулярность, подчеркнутая отделением строф пробелами, непредставимое в других традиционных формах прозы отсутствие заголовка» (Орлицкий 2008: 16). Графическое членение на строки, получается, не столь уж необходимо. Заметим, почти все из перечисленного - это то, что можно определить как явления симметрии. Но почему названные фрорманты «вторичные»? Если это так, то вторичное должно системно выводиться из первичного, а первичное исторически может и сниматься. На деле же этого не происходит. Значит, не членение на строки, а нечто иное является движущей силой стиха. Даже такая, предельно широкая и поэтому малосодержательная концепция, как «двойная сегментация», оказалась слишком узкой для фрольклористики. Если наука о стихе будет и дальше идти по этому пути, то она зайдет в тупик.

\section{Вместо заключения}

То, к чему мы в конце концов пришли, вкратце можно сорормулировать так: если «сегментация», то не двойная, а если «двойная», то не сегментация. С одной стороны графика, с другой декламация и пение представляют собой речевые акты, а не собственно стихотворную речь. Членение стихотворной речи многослойно, необходимо отличать внешние членения от внутренних. И, тем не менее, сколько бы ни насчитывалось членений, существуют именно два принципа организации текста: симметричный и диссиметричный, между которыми в пространстве материального плана происходит единоборство, «единство и борьба» ${ }^{20}$. Но 
в стихе не два синтаксиса, а один, как и в прозе, стиховое членение никакого отношения к синтаксису не имеет. Единственная связь стихового членения с синтаксисом в том, что элементарная единица стиха (колон) образуется на синтаксическом уровне из речевой синтагмы и на раннем этапе становления полностью совпадает с синтагмой, поскольку в фольклоре не наблюдается анжамбеманов. Анжамбеман, как и графическая строка, сравнительно позднее явление, кроме того, он спорадичен. Колон же, регулярно совпадая с синтагмой, тем не менее, отличается от нее. Чем же? На фольклорном этапе стиха колон был и остается парцелированной синтагмой. Явление стиха знаменуется не количеством сегментаций, а п а р це л л я ци е й материального плана, что не одно и то же.

Сравним парцелляцию (разметив вертикальными слэшами: | | - колон; | | | - строка, период) и сегментацию (наклонными слэшами: // - синтагма; /// - фрраза) на примере из Максима Богдановича (Б.: 33):

Вось псальма слічная. | | "Як той алень шукае | | |

Крыніцы чыстай, так | | шукаю Бога я”. | | |

Як вее свежасцю | | яе краса жывая! | | |

Як радасна далей | | спяшыць душа мая! | | |

Вось псальма слічная. /// "Як той алень // шукае

Крыніцы чыстай, // так шукаю Бога-я”. ///

Як вее свежасцю // яе краса-жывая! ///

Як радасна // далей спяшыць // душа-мая! ///

Отрывок представляет собой чисто литературный текст, усложненный анжамбеманами. Нетрудно заметить, что даже в таком позднем тексте много совпадений в членении, но, тем не менее, отличия наблюдаются, и не только между колонами и синтагмами, акцентами и иктами. Даже синтагматическое ударение в синтагме так шукаю Бога-я не совпадает с константой колона шукаю Бога $\boldsymbol{я}$ - под воздействием метра и рифрмы ударение переносится с существительного на местоимение - грамматически слабое и семантически менее значимое слово. С другой стороны, членение на синтагмы изменчиво, возможно и эмфатическое выделение местоимения, а в колоне дистрибуция сильных позиций предопределена заранее метрикой (но не графрикой!).

Если термин сеглент трактовать в суженном смысле и понимать как отрезок, имеющий материальное начало и конец, 
то не всякая сегментация сопровождается парцелляцией и наоборот. Именно в этом загадка стопы. Мы знаем, что в фольклоре колон практически совпадает с синтагмой, поэтому он является и сегментом, и парцеллой, стопа же - парцелла, но не сегмент. Потому ей и отказывали в существовании, поэтому она в некоторых пределах условна, - допускает и ямбо-хореическое и пеоническое шкалирование. Здесь мы не можем дать исчерпывающего ответа, как порождается стопа, лишь вкратце постараемся наметить его. Если сравнить единицы разных уровней, то звук, независимо от типа речи, является и знаком (реализацией фонемы), и сегментом, парцеллой же пока не является, слог уже является и сегментом, и парцеллой, но перестает быть знаком, а фонетическое слово и синтагма лишь сегменты, но в фольклорном стихе они парцеллируются - не членением, а селекцией. Позже происходит размежевание парцелл с сегментами - явление анжамбемана, расчлененное может вторично члениться. А также развивается внутренняя парцелляция - возникают стопы, которые эволюционируют и модифицируются.

Вместе с «двойной сегментацией» мы вынуждены отвергнуть и строку как первоэлемент стиха. Если «двойная сегментация» неспособна охватить все значимые для стиха уровни, то строка, помимо всего прочего, статична, не обладает необходимым порождающим потенциалом. Строка выдвигается в пределах формально-логической игры: отыскать некую всеобъемлющую и вневременную характеристику стиха. И дело не в том, что эта игра постоянно проигрывается, а ее победы пирровы, дело в том, насколько она существенна. В результате игры создается конвенция, не имеющая практической пользы. Альтернативу этой игре мы видим в системном и историческом подходе. Но находимо ли то существенное, способное объединить и фольклорный стих, и классический литературный, и модерный? Для нас важен лишь порождающий момент и именно такой, который позволит уразуметь стихотворную речь, от истоков до современности, как иерархически организованное целое на фоне иерархии языка. Иначе говоря, необходима не стабильная, вневременная характеристика, а точка отсчета, где происходит качественный скачок от прозы к стиху. Но это не следует понимать так, что сначала проза, а потом стих («Исторически поэзия и проза, как стиль, могли и должны были появиться одновремен- 
но» (Веселовский 1992: 296)). Важна не стабильность форманта, но активность, способность активизировать текст сверху донизу, а также присутствие на ранних этапах. Всем этим требованиями удовлетворяет лишь один формант - и з ос и л л а б и з м .

Такой вывод, особенно, в контексте русской традиции, где силлабика занимала маргинальное положение и имела самое негативное восприятие, может показаться плохой шуткой. Но именно силлабический стих находится у истоков если не каждой, то почти каждой национальной традиции. Мы уверены, что более пристальный взгляд на историю стиха выявит силлабику даже там, где она не рассматривалась. Иногда считается, будто элементарная единица силлабического стиха - слог, это не соответствует действительности ни с исторической, ни с практической, ни с теоретической точки зрения ${ }^{21}$. На самом деле, элементарная единица силлабического стиха - колон, а точнее - изоколон. В соизмеримых колонах возникает то внутреннее напряжение, из которого порождается метрика. Изосиллабизм - это достаточное основание, чтобы все уровни текста взаимодействовали не как сумма единиц, а как новое системное целое. Метрику нельзя придумать, если она не предзадана как фрункция языка, раскрывающаяся по-разному в разных условиях ${ }^{22}$. Есть основания полагать, что лишь хорей может считаться немаркированным метром, другие же метры - его дерриваты, но это требует основательной проверки, как и другие положения нашего заключения. Мы намеренно не ограничиваемся лишь выводами, а намечаем перспективы, ради которых и создавался этот текст.

\section{Примечания}

1 Имеется в виду фонетическое слово

2 Здесь, кроме нескольких, специально оговоренных случаев, имеется в виду синтагма в том значении, которое придавал термину Л. В. Щерба, - синтагма как часть фразы. Ее необходимо отличать от синтагмы в том значении, которое придавал термину $Ф$. де Соссюр, - синтагма ${ }^{\mathrm{s}}$ как цепочка из двух и более элементов какого-либо уровня языка, см. разные точки зрения на этот счет (Виноградов 1975; Реформатский 1975).

3 Была прочитана впервые как доклад в 1962 г. на IX международном конгрессе лингвистов. 
4 В отличии от просодемы, выполняющей интегрирующую и смыслоразличительную функции, синдема, по С. Д. Кацнельсону (Кацнельсон 1986: 188-189), выполняет лишь интегрирующую функцию.

5 При этом ядерный элемент уровня фонем - синдема / просодема - заметнее на лексическом уровне, чем на морфологическом, что косвенно подтверждает относительность разграничения морфологического и лексического уровней.

6 Именно поэтому их собственные характеристики - объем и внутренний ритм - случайны и хаотичны.

7 В. В. Виноградов развивал учение Л. В. Щербы о синтагме.

8 Понятие «ритм прозы» очень запутало дело, поэтому Л. И. Тимофеев пробовал возражать: «Ритма в прозе нет» (Тимофеев 1928: 30). Следует помнить и это: «Метры - особые виды ритмов» (Аристотель 1957: 49).

9 Об аналогичном влияние графики, только по иному поводу, писал С. Д. Кацнельсон: «Дуалистический образ двух линейных рядов, из которых один (сегментный) является базисным, а другой (суперсегментный) - надстроечным, навеян, без сомнения, алфавитной графикой, в которой знак акцента витает над словом как внешний и малозначимый для него элемент» (Кацнельсон 1986: 186).

10 Трансцендентальное по И. Канту не то, что выходит за пределы опыта (т. е. трансцендентное), а то, что ему предшествует, делая возможным сам опыт.

${ }^{11}$ В моносиллабических языках фонем не существует, но есть силлабемы, а морфема и слово соответствуют слогу, это, по-видимому, важная деталь и для стихосложения.

12 Правда, звуки имеют значение для сопутствующих, локальных формантов стиха, таких как рифмы, аллитерации и т. п. Но, хотим мы того или нет, из логики построения т. н. звуковых повторов мы никогда не придем к логике построения слога, а значит - не выстроим и всей пирамиды стихотворной речи - на этих уровнях стих еще не начинается.

${ }^{13}$ Есть, конечно, и понятие риторического колона, но, если это не та же синтагма (см. разные точки зрения: Виноградов 1975: 116-117; Реформатский 1975: 26-27), то «ораторская проза, воспринимаемая как область риторики par excellence, может быть описана как результат вторжения поэзии в область прозы» (Лотман 1995: 104-105).

${ }^{14}$ У А. Х. Востокова колон фигурирует как "прозодический период» (классический период по уровню выше), а у И. И. Срезневского (Срез- 
невский 1959) и А. А. Потебни (Потебня 1884) как «синтаксическая стопа» (классическая стопа по уровню ниже).

${ }^{15}$ Разница между ними в том, что симметрия - симультанна, а ритм сукцессивен, сводимы ли они друг к другу и что является частным случаем другого, пока оставим в стороне.

${ }^{16}$ Может быть разная степень редукции речевого акта, например, А. А. Банин предлагает записывать песни, «абстрагируясь от звуковысотного компонента мелодии», что поможет «точно зафиксировать пропорции музыкального времени, существующие между слогами текста в данном напеве» (Банин 1982: 105).

${ }^{17}$ Гексон - шестисложная экспериментальная стопа, предложенная В. Пястом (Пяст 1931: 292), здесь следует понимать как модификацию ямба или хорея.

${ }^{18}$ Свойства сильных иктов были известны уже в начале XIX в., Д. Дубенский называл их «коренными»: «В стихе чувствуем два или три (в зависимости от общего количества стоп, - Ю. П.) коренные тона, которым подчинены другие, тихие» (Дубенский 1828: 8).

${ }^{19} \mathrm{Cp} .:$ «Народная музыка, в изобилии пользующаяся паузами структурного характера, почти не знает пауз тематических, то есть пауз образно-выразительных» (Елатов 1966: 47).

${ }^{20}$ Еще менее уместно применение здесь вместо «двойной сегментации» термина "двойное кодирование», так как в этом случае материальный план путается с сигнификативным, но, как только мы покидаем пределы лингвистики и обращаемся к поэзии как искусству (а не исключительно стиху), т. е. обращаемся ко второй моделирующей системе, термин «кодирование» по отношению к игре симметрии/ диссимметрии вполне уместен, хотя о количестве кодирований говорить сложно.

${ }^{21}$ Слоги парцеллируют всякую речь, поэтому они не могут быть мерой стиха. Кроме того, «без акцентов нет ритма» (Теплов 1985: 188).

${ }^{22}$ См. наши работы: (Пацюпа 2014-2016; Пацюпа 2016; Пацюпа 2016а).

\section{Список источников}

А. - Александровіч, Андрэй 1963. Збор твораў. У 2 m. T. 1: вершы. Мінск: Дзяржаўнае выдавецтва БССР.

АЖП - Анталогія жаночае паэзіі 2001-2002. Саламея: выданне для саластойныцх жанчыьн. Гродна, 2001: №№ 10-12; 2002: № 14. 
Б. - Багдановіч, Максім 2014. Творы. Мінск: Мастацкая літаратура.

Кл. - Колас, Якуб 2007. Збор твораў. У 20 m. T. 1: вершы. Мінск: Беларуская навука.

Кп. - Купала, Янка 1995-1996. Збор твораў. У 9 m. T. 1: вершы, пераклады 1904-1907. Т. 2: вершы, пераклады 1908-1910. Мінск: Мастацкая літаратура.

HН - Hаша Нiва 1907, № 19 (18 мая).

ПЗК - Паэзія беларускага зелляробчага календара 1992. Мінск: Навука і тәхніка.

Хр. - Беларуская літаратура ХІХ стагоддзя: хрэстаматыя 1988. Мінск: Вышэйшая школа.

\section{Литература}

Аристотель 1957. Об искусстве поэзии. Москва: Государственное издательство художественной литературы.

Банин, Александр 1982. К изучению русского народно-песенного стиха: методологические заметки. Фольклор 1982: Поэтика и традиция. Москва: Наука, сс. 94-139.

Барт, Ролан 1989. Избранные работы: Селиотика. Поэтика. Москва: Прогресс.

Бенвенист, Эмиль 1974. Общая лингвистика. Москва: Прогресс.

Бондарко, Лия \& Вербицкая, Людмила \& Гордина, Мира 1991. Основы общей фбонетики: учеб. пособие. Санкт-Петербург: Издательство С.-Петербургского ун-та.

Бухштаб, Борис 1969. О структуре русского классического стиха. Ученые записки Тартуского университета. Вып. 236. Труды по знаковыли систелам 4. Тарту, 1969, сс. 386-408.

Востоков, Александр 1817. Опыт о русском стихосложении. СанктПетербург.

Веселовский, Александр 1989. Историческая поэтика. Москва: Высшая школа. 
Виноградов, Виктор 1975. Понятие синтагмы в синтаксисе русского языка (Критический обзор теорий и задачи синтагматического изучения русского языка). Виноградов, Виктор. Избранные трудь:: исследования по русской граллатике. Москва: Наука, сс. 88-154.

Волков, Александр 1966. Язык как систела знаков. Москва: Издательство Московского университета.

Гаспаров, Михаил 1965. Вольный хорей и вольный ямб Маяковского. Вопросы языкознания 3, сс. 76-88.

Гаспаров, Михаил 1967. Акцентный стих раннего Маяковского. Ученые записки Тартуского университета. Вып. 198. Труды по знаковылм системал 3, сс. 324-360.

Гаспаров, Михаил 1974. Современный русский стих: Метрика и ритлика. Москва: Наука.

Гаспаров, Михаил 1980. В поисках «настоящего верлибра». Литературная учеба 6, сс. 208-211.

Гаспаров, Михаил 2000. Очерк истории русского стиха: Метрика. Ритлика. Рифбма. Строфбика. Москва: Фортуна Лимитед.

Гаспаров, Михаил 2004. Русский стих начала XX века в комлентариях. Москва: КДУ.

Гончаров, Борис 1972. Интонационная организация стиха Маяковского. Русская литература 2, сс. 77-97.

Гончаров, Борис 1970. О паузах в стихе Маяковского. Русская литература 2, сс. 47-61.

Давыдов, Данила 2008. Стиховая утопия. Квятковский, Александр. Ритмология. Санкт-Петербург: ИНАПРЕСС, изд-во «Дмитрий Буланин», сс. 704-711.

Денисов, Яков 1888. Основания метрики у древних греков и римлян. Москва, Типография Елизаветы Гербек.

Дубенский, Дмитрий 1828. Опьт о народнол русскол стихосложении. Москва: Университетская типография.

Елатов, Виктор 1966. Ритлические основы белорусской народной музыки. Минск: Наука и техника. 
Кацнельсон, Соломон 1986. Фонемы, синдемы и «промежуточные» образования. Кацнельсон, Соломон. Общее и типологическое языкознание. Ленинград: Наука, сс. 186-192.

Квятковский, Александр 1966. Поэтический словарь. Москва: Советская Энциклопедия.

Квятковский, Александр 2008. Ритлология. Санкт-Петербург: ИНАПРЕСС, издательство «Дмитрий Буланин».

Квятковский, Александр \& Колмогоров, Андрей 2008. «В природе ритмических процессов лежит число...»: Переписка А. П. Квятковского и А. Н. Колмогорова. Вопросы литературы 4, сс. 5-38.

Кенигсберг, Максим 1994. Из стихологических этюдов: 1. Анализ понятия «стих». Philologica 1 (1/2), сс. 149-185.

Колмогоров, Андрей \& Кондратов, Александр 1962. Ритмика поэм Маяковского. Вопросы языкознания 3, сс. 62-74.

Колмогоров, Андрей \& Прохоров, Александр 1964. О дольнике современной русской поэзии. (Статистическая характеристика дольника Маяковского, Багрицкого, Ахматовой). Вопросы языкознания 1, cc. $75-94$.

Колмогоров, Андрей 1963. К изучению ритмики Маяковского. Вопрось языкознания 4, сс. 64-71.

Колмогоров, Андрей 1965. Замечания по поводу анализа ритма «Стихов о советском паспорте» Маяковского. Вопросы языкознания 3, cc. $70-75$.

Кондратов, Александр 1962. Эволюция ритмики Маяковского. Вопросы языкознания 5, сс. 101-108.

Лотман, Юрий 1970. Структура художественного текста. Москва: Искусство.

Лотман, Юрий 1995. Риторика. Риторика: спеииализированный проблелный журнал 2, сс. 92-108.

Мухин, Анатолий 1976. Лингвистический анализ: Теоретические и методологические проблель. Ленинград: Наука.

Невзглядова, Елена 1994. Проблема стиха: (На материале русской лирической поэзии). Русская литература 4, сс. 67-91. 
Орлицкий, Юрий 2008. Динамика стиха и прозы в русской словесности. Москва: РГГУ.

Пацюпа, Юры 2014-2016. Законы рытму і прырода выклічнікаў. Роднае слова, 2014: № 8, сс. 23-26; № 9, сс. 22-25; № 11, сс. 19-24; 2015 . № 1, cc. 29-34; № 4, cc. 25-31; 2016: № 2, cc. 18-23.

Пацюпа, Юры 2016. Вершаванне ў замовах: Паводле матәрыялаў Віцебшчыны і Гродзеншчыны. Беларускі фбальклор: Матэрыяльь і даследаванні: Зборнік навуковых прац. Вып. 3. Мінск: Бел. навука, cc. 146-197.

Пацюпа, Юры 2016а. Народнае вершаванне. Нарысы гісторыі культуры Беларусі. У 4 m. Тол 3: Культура сяла. Мінск: Беларуская навука, сс. 651-677.

Печоров, Георгий 1970. О синтагментной ритмике стихов В. В. Маяковского. Вопросы фбилологии. Ученые записки Куйбышевского педагогического института. Вып. 74. Куйбышев, cc. $146-164$.

Печоров, Георгий 1971. Об изучении ритмики В. В. Маяковского. Русская литература ХХ века: Советская литература. Ученые записки Московского педагогического института 456. Москва, 1971, сc. 323-343.

Потебня, Александр 1884. Обзор поэтических мотивов колядок и щедровок: І. Размер. Русский фбилологический вестник 11 (1), сс. 1-32.

Пяст, Владимир 1931. Современное стиховедение: Ритлика. Ленинград: Издательство писателей в Ленинграде.

Реформатский, Александр 1975. Пролегомены к изучению интонации. Реформатский, Александр. Фонологические этюды. Москва: Наука.

Роднянская, Ирина 2008. Комментарии. Квятковский, Александр. Ритлология. Санкт-Петербург: ИНАПРЕСС, изд-во «Дмитрий Буланин», сс. 673-700.

Руднев, Петр 1989. Введение в науку о русском стихе. Вып. І. Тарту: (ТГУ).

Руднева, Анна 1994. Русское народное музыкальное творчество: очерки по теории фбольклора. Москва: Советский композитор.

Слюсарева, Наталья 1969. О некоторых проблемах иерархической организации языка. Единицы разных уровней гралматического строя языка и их взаилодействие. Москва: Наука, сс. 269-273. 
Срезневский, Измаил 1959. Мысли об истории русского языка (Читано на акте Илператорского Санкт-Петербургского университета, 8 бевраля 1849 года). Москва: Государственное учебно-педагогическое издательство.

Тарановский, Кирилл 2000. О ритмической структуре русских двусложных размеров. Тарановский, Кирилл. О поэзии и поэтике. Москва: Языки русской культуры, сс. 274-282.

Теплов, Борис 1985. Избранные труды. В 2 m. T. 1. Москва: Педагогика.

Тимофеев, Леонид 1928. Ритм стиха и ритм прозы (О новой теории ритма прозы М. А. Пешковского). На литературнол посту 19, cc. $20-30$.

Томашевский, Борис 1959. Стих и язык: Филологические очерки. Москва $\&$ Ленинград: Государственное издательство художественной литературы.

Томашевский, Борис 2008. Проблема стихотворного ритма. Томашевский, Борис. Избранные работы о стихе. Санкт-Петербург: Филологический факультет СПбГУ; Москва: Издательский центр «Академия», сс. 24-52.

Трахтеров, Александр 1956. Основные вопросы теории слога. Вопросы языкознания 6, сс. 15-32.

Тынянов, Юрий 1965. Проблема стихотворного языка. Статьи. Москва: Советский писатель.

Холшевников, Владислав 1987. Что такое русский стих. Мысль вооруженная рифљали: Поэтическая антология по истории русского стиха. Ленинград: Издательство Ленинградского университета, cc. $5-36$.

Чудовский, Валериан 1915. Несколько мыслей к возможному учению о стихе (с примерным разбором стихосложения в I главе «Евгения Онегина»). Аполлон 8-9, сс. 55-95.

Шапир, Максим 1996. Стих и проза: Пространство-время поэтического текста (Основные положения). Славянский стих: Стиховедение, лингвистика и поэтика: материальлмеждународной конферениии 19-23 июля 1995 г. Москва: Наука, сс. 41-49.

Эйхенбаум, Борис 1969. О поэзии. Ленинград: Советский писатель. 


\section{Summary}

\section{The Relation between a Verse and Its Visual and Oral Representation: On the Issues of Poetic Speech}

\section{Jury Paciupa}

Keywords: asymmetry, chanting, colon, construct, declamation, dissymmetry, element, foot, language, level, parcellation, period, phrase, poetry, prose, recitation, segmentation, speech, syllable, symmetry, syntagma, visual presentation, word

An important aim of poetics is stratification of verse levels in relation to language and speech stratification. By achieving this aim, we can reveal the relations between verse and oral and written speech acts and study effectively both oral folklore and literary texts. The paper systematically discusses the relations between different levels and layers of language, speech and verse. The suggested solution develops and deepens the hierarchical verse model that was created in the Classical antiquity time. The author uses multiple examples to prove that the structure of verse cannot be reduced neither to its visual presentation nor to its performance and critically revisits the popular understanding of verse as speech with "double segmentation". A careful study of poetry visual presentation and its verbal structure reveals complex relations between symmetry and asymmetry that can be regarded as the roots of verse and prose accordingly. Based on these conclusions, the author shows anti-declamatory postulates in poetics and suggests the distinction between the three ways of poetry reading: chanting, recitation and declamation, the latter one is subdivided into melodious and rhetoric reading. The author focuses his attention on recitation, as it the way of reading that allows to diagnose rhythm variations and modifications. The author's conclusion is that poetic speech is performed by parcellation of material segments and the basic item of poetic speech is isocolon; isosyllabism is the mechanism that activates all the levels of speech and can create metrics. 


\section{МИССИЯ ВЫПОЛНИМА Перспективы изучения фольклора}

http://www.folklore.ee/rl/pubte/ee/sator/sator19/

ISSN 1736-0323

ISBN 978-9949-586-60-8

DOI: $10.7592 /$ Sator.2018.19

Тарту 2018

Редакторы-составители выпуска:

Маре Кыйва \& Татьяна Володина

Редактор серии: Маре Кыйва

Фото: Яак Кикас, 2018 «Осень в Тарту»

Оформление обложки: Лииса Весик

Верстка \& HTML: Диана Кахре

Печатное издание: МИССИЯ ВЫПОЛНИМА:

Перспективы изучения фольклора. SATOR 19. Тарту 2018

Публикация книги осуществлена совместно Эстонским литературным музеем и Центром исследований белорусской культуры, языка и лит ерат уры Националь ной акад емии наук Б еларус и, п ри поддержке Министерства образования и науки Эстонии (IUT 22-5), Фонда регионального развития ЕС (ТK 145, Центр компетенции по Эстонским исследованиям); при поддержке проекта, финансируемого Министерством иностранных дел Эстонии из бюджета по сотрудничеству и развитию, Эстонской Академией Наук и Национальной академии наук Беларуси.

Оформление электронного издания осуществлено при поддержке проекта ЕККМ14-344 “Расширение областей применения и представление эстонского языка, культуры и фольклора в электронных информационных средствах".

() Эстонский литературный музей

(c) Авторы

(с) Яак Кикас 